\title{
DA VOZ Á LETRA, DA PLUMA AO PRELO. ESCRITA E LECTURA DOS VERSOS GALEGOS DE ROSALIAA
}

Henrique Monteagudo

Instituto da Lingua Galega / USC

doi: 10.17075/rcsxxi.2014.019 

Álvarez, R. / A. Angueira / M. C. Rábade / D. Vilavedra (coords.) (2014): Rosalía de Castro no século XXI. Unha nova ollada, Santiago de Compostela, Consello da Cultura Galega. doi:10.17075/rcsxxi.2014. pp. 349-404

Historias dinas de ser cantadas por mellores poetas d'o qu'eu son, e cuyas santas armonias deberan ser espresadas c'un-ha soya nota e n'un-ha soya corda.

"As multitudes d'os nosos campos tardarán en lêr estos versos, escritos á causa d'eles, pero sô en certo modo para eles», prevé Rosalía de Castro, en lúcido vaticinio, no limiar de Follas novas. Aquelas multitudes aínda eran en boa parte analfabetas, unha condición que fora evocada pola propia autora nun dos seus Cantares gallegos, en que nos presenta un quinto destinado a Cuba que se dirixe á súa Rosińa animándoa a que cumpra a promesa que lle fixera de que aprendería a ler, e dándolle conta dos seus propios progresos no aprendizado das letras: «Dime tamen si deprendes / Pó la cartilla de Cristus / A lér como m’ofreceches / Para ler os meus escritos, / Qu'en sabendo algun-has letras / Dempois irás traducindo. / Eu xa lle perdin ó medo / A escribiduras e libros / Pois fago uns palotes netos / De qu'eu mesmo m'adimiro» $\left(\mathrm{CG}_{1} \text {, núm. } 22\right)^{1}$. Pero se a multitude galegofalante «d'os nosos campos» era analfabeta, o propio idioma, «sin gramática nin regras de ningun-ha clas» — como a propia Rosalía afirma no prólogo dos Cantares — era case totalmente ilítero.

Esas dúas circunstancias son determinantes da peculiar maneira en que se articulan oralidade e escrita nos textos rosalianos en galego: nestes, o soporte da escrita é pouco máis ca un rexistro de trámite de textos orais, tanto na súa orixe coma no seu destino. Na súa orixe, xa que eran recibidos (no caso dos versos tomados de coplas populares) ou compostos (no caso dos versos fabricados pola autora) oralmente, isto é, 'en voz alta'. No seu destino, dado que están pensados para ser escoitados, ben trasladados a voz (alta ou baixa) polo lector individual que descodifica o seu rexistro gráfico cos ollos e coas cordas vocais, ben oídos por un público ao que lle chegan por boca de alguén que os recita. De certo, o devandito é máis acaído para Cantares gallegos ca para Follas novas: o título do primeiro libro evoca directamente a oralidade (a lingua non só falada, senón cantada), 
mentres que o do segundo remite á páxina, á lingua escrita. Aínda así, a poesía de Rosalía (en galego) só pode captarse cabalmente cando é posta en son ou en solfa pola voz, no recitado ou no canto: a cita rosaliana da nosa epígrafe inicial dá unha pauta clara nese sentido. E isto nin é casual nin é sen consecuencias, como tentaremos mostrar, fixando a nosa atención na obra primeira de Rosalía en galego.

\section{O CONTEXTO HISTÓRICO LINGÜÍSTICO. O GALEGO ESCRITO NO SÉCULO XIX}

De feito, a historia da escrita do galego (coma a de calquera outro idioma) é en boa parte a crónica da progresiva autonomización do código gráfico a respecto da oralidade. Esta autonomización implica, por unha banda, a análise cada vez máis requintada da cadea sonora, isto é, a identificación das unidades constitutivas básicas do idioma (fonemas, morfemas, palabras, frases, oracións...) —o que pola súa vez implica desentrañar a sistemática subxacente aos complexos fenómenos de variación diatópica, diastrática e estilística, en particular, os de carácter fonotáctico, que caracterizan a lingua oral—, e, por outra banda, a creación e adopción dos recursos gráficos, gramaticais, léxicos e discursivos que lle son propios á lingua escrita e a caracterizan fronte á oralidade. Con todo, debemos coidarnos de pensar que ese proceso de autonomización seguiu unha progresión lineal nunha única dirección. Aínda que os gramáticos e lingüistas colaboraron decisivamente nas devanditas operacións mediante a reflexión consciente sobre os problemas que estas suscitan, perante a falta dunha tradición gramatical minimamente vigorosa e institucionalizada unha parte moi importante do labor quedou en mans dos cultivadores do idioma, que obraron de xeito en xeral intuitivo e escasamente sistemático.

Así, no galego escrito durante o século xix é posible distinguir dúas etapas claramente diferenciadas (retocamos no que vén a seguir a proposta que ofrecemos en Fernández Salgado / Monteagudo 1995 e Monteagudo 2003). Nunha primeira etapa, que vai desde as primeiras tentativas dos inicios ata aproximadamente a metade do século (digamos aproximadamente de J. Fernández y Neira ata J. M. Pintos Villar), aínda non se producira a selección da norma fónica, de xeito que fenómenos coma a gheada e o seseo, ulteriormente silenciados, atopan o seu 
reflexo específico na escrita. Por parte, non se manifesta unha tensión diferencialista verbo do castelán, pois non cremos que por baixo dos ensaios de representación deses dous fenómenos, en si mesmos 'distanciadores' (gheada e seseo), latexe unha intención deliberadamente diferencialista. A Gramática Gallego-Castellana de Francisco Mirás (1864), coa súa opción dialectalizante a prol da gheada e o seseo gráficos, expresa un estadio de consciencia lingüística que correspondería a esa primeira etapa máis ca ao Rexurdimento propiamente dito.

Nunha segunda etapa do galego contemporáneo escrito, que comeza por volta da metade do século XIX, maniféstanse dúas tendencias contraditorias. A primeira arrinca de J. M. Pintos, quen se sitúa claramente no ronsel do maxisterio de Sarmiento. En principio maioritaria, é de orientación cultista. Así, dunha banda, aposta pola etimografía (gente, ja, deixar) e, doutra, por unha escrita simplificada, evitando ou reducindo ao máximo o emprego de sinais diacríticos (singularmente, o apóstrofo), aptos para a representación gráfica de fenómenos fonotácticos. Esta opción é a preferida polos 'precusores' da xeración anterior a Rosalía: desde o xa citado J. M. Pintos (nado en 1811) ata Antonio María de la Iglesia (n. 1822) — talvez os seus máis acaídos representantes—, pasando por Francisco Añón (n. 1812) ou Marcial Valladares (n. 1821). Continuador desta tradición, xa da mesma xeración de Rosalía, será Eduardo Pondal (n. 1835), e na posterior poden citarse outros membros do círculo corunés da Cova Céltica, como Francisco Tettamancy y Gastón (n. 1854) ou Florencio Vaamonde Lores (n. 1860).

Unha obra representativa desta tendencia é $A$ Gaita Gallega. Carta de Cristus para ir deprendendo a ler, escribir e falar a lengua gallega (1853), que vén sendo, sen dúbida, a obra máis importante dos anunciadores do Rexurdimento. Consiste nun tratado de carácter didáctico que contén elementos de ortografía, léxico e etimoloxía, textos exemplificativos e unha rexa doutrina en defensa do idioma. Como dixemos, a obra de Pintos, convencido etimoloxista, está fortemente influída por Sarmiento, a quen dedica un panexírico ao final do libro. O maxistrado pontevedrés demostra un criterio lingüístico atinado e sólido, de xeito que temos motivos para laiarnos de que a súa doutrina non deixase un ronsel máis amplo e permanente. Outra das obras que mellor ilustra o que acabamos de dicir acerca do predominio da tendencia cultista entre os precusores de Rosalía é o Album de la Caridad, antoloxía poética publicada en 1862, que inclúe composicións de todos os devanditos e outros máis (Vicente Turnes, Alberto Camino, 
Francisco M. de la Iglesia, J. Pérez Ballesteros, o propio M. Murguía...) e tamén de Rosalía de Castro, como máis adiante mostraremos en detalle. Antonio María de la Iglesia foi un dos impulsores e protagonistas indiscutibles do Rexurdimento non só como editor do Album de la Caridad e da publicación Galicia. Revista Universal de este Reino (1860-65), senón porque o seu contributo como antólogo e divulgador das letras galegas aínda floreceu na importante colectánea en tres volumes El idioma gallego. Su antigüedad y vida (1886). Tanto no Album coma nesta antoloxía, Antonio de la Iglesia impuxo o seu rigoroso criterio etimográfico, revisando e uniformizando ortograficamente os textos.

Pero na referida segunda etapa do galego escrito no século XIX emerxe con forza outra tendencia, de carácter decididamente popularista, da que autores como Rosalía de Castro, Manuel Curros Enríquez e Valentín Lamas Carvajal son acaídos representantes. Na escrita destes autores maniféstase unha vontade explícita de diferenciación da ortografía galega verbo da castelá 2 . Con esta vontade está intimamente relacionada a percepción, amplamente sentida polos cultivadores do galego nesa época, de que cumpría que a oralidade galega fose rexistrada na escrita coas súas peculiaridades e coa maior exactitude posible. Dada a falta dunha tradición de cultivo escrito, xulgábase que o máis característico, distintivo, do idioma galego eran as particularidades da súa pronuncia: o mesmo prólogo de Cantares está acugulado de referencias auditivas: «arrulo incesante de palabras mimosas e sentidas», a "aquel dialecto soave e mimoso [...] que aventaxa âs demais linguas en doçura e armonia», a "aquelas palabras cariñosas e aqueles xiros nunca olvidados que tan doçemente resoaron nos meus oidos», en fin a "ó noso dialecto doce e sonoro" (as cursivas son nosas). Reivindícanse, fronte ao estigma dominante que o denigraba por brután e inculto, unhas características do idioma (dozura, harmonía, sonoridade, mimo) que remiten á súa pronuncia, ou, máis exactamente, a como prestaba ao oído, a como soaba —en definitiva, á súa música, o seu son. É que non existían grandes escritores nin textos literarios admirables a que remitirse.

O esforzo por plasmar na escrita aquelas peculiaridades do galego falado — un propósito que, agora si, responde a unha motivación autoidentificadora e dife-

2 A primeira achega a unha caracterización xeral da escrita galega deste período ofreceuna Alonso Montero 1970. Máis recente, e incidindo especialmente no aspecto ortográfico, Lorenzo 1986. Unha panorámica xeral ofrecémola en Monteagudo 2003, 46-52. Cunha análise completamente diferente á nosa e a estes dous estudosos, e centrándose máis no léxico, véxase Carvalho Calero 1983. 
renciadora fronte ao castelán - provoca, como a análise dos textos primeirizos da nosa autora mostrará, a mobilización de todo o aparello de apóstrofos, trazos e outros recursos que ofrecen unha fasquía visual tan enmarañada e tan característica — et pour cause! - aos textos galegos escritos nese período. Representativo desta tendencia é o máis importante tratado lingüístico do período: a Gramática gallega de J. A. Saco Arce (1868), un clérigo ourensán con sólida formación e criterio tamén moi asisado, que, aínda que non pretendeu realizar unha codificación sistemática, exerceu unha considerable influencia sobre os cultivadores do idioma, especificamente no terreo ortográfico; como testemuña explicitamente, entre outros, M. Curros Enríquez — véxase Monteagudo 2004.

Podemos falar, pois, dunha etapa inicial de 'galego circunstancial' e dunha etapa posterior de 'galego poético', que tería continuidade nunha fase ulterior de 'galego culto'. Na segunda etapa, maniféstanse dúas tendencias, unha delas máis cultista e etimográfica, adoito con certo pendor pasatista e un sabor elitista e aristocratizante; a outra máis popularista e fonográfica, con vocación máis demótica e divulgativa. Enténdase ben: durante todo o século, o galego non pasou dunha fase de 'literacidade incipiente', o que significa que os textos escritos dependían máis ou menos servilmente da oralidade, unha dependencia pola que pularon de desprenderse os autores de tendencia cultista. A diferenza entre o galego circunstancial escrito durante as primeiras décadas do século e o galego popularista da segunda metade do mesmo radica en que na primeira o rexistro escrito da lingua falada non atendeu tanto aos aspectos fonográficos (excepción feita da gheada e o seseo, de ser o caso), e si aos morfosintácticos, estilísticos e discursivos: búscase unha representación fiel da 'lingua falada' (en particular, do seu rexistro coloquial), e non tanto da 'fala' (isto é, dos aspectos propiamente fónicos da lingua oral). Pola contra, a tendencia popularizante que se vai desenvolvendo na segunda metade do XIX esfórzase por ofrecer un reflexo gráfico tamén destes aspectos fónicos da oralidade. Para entendérmonos, na primeira etapa efectúase un 'rexistro' do galego falado informal, riquísimo de modismos, xiros e expresións coloquiais; na segunda os autores popularistas pretenden case unha 'transcrición' deste, inzada das elisións, contraccións, metástases e outros fenómenos típicos do falar distendido.

Para explicar esta mudanza, débese ter en conta que o que primou na etapa 'circunstancial' foi a prosa, mentres que na etapa posterior o xénero dominante foi 
a poesía. A poesía cultista abrigaba outras pretensións, pero a poesía popularista pugnaba por recrear a fala común. Aínda que tanto unha coma outra - que, como acabamos de sinalar, se atopaban nun estado de literacidade 'incipiente'foron escritas 'de oído' e 'para o oído' (a prosa panfletaria das primeiras décadas do século chegaba á súa audiencia mediante a lectura en voz alta ante un público iletrado), o certo é que a poesía popularista, dada a importancia que nela teñen factores puramente sonoros coma a rima e o ritmo (a poesía decimonónica aínda é unha poesía 'recitada', aínda que sexa só mentalmente), esixe unha maior atención aos aspectos fónicos da lingua falada, e isto quizais convidou a pór un maior coidado en rexistralos con fidelidade. Esta nova formulación da relación entre código gráfico e rexistro oral en galego colocou unha manchea de problemas de non doada solución, e que ían repercutir na escrita do galego ata case a metade do século XX.

Cando está fixada unha tradición ortográfica, os lecto-escritores que seguen esa tradición xa reciben, mediante as mesmas prácticas que esta institúe, unha determinada análise da cadea oral, unha análise que, se a tradición escrita está plenamente 'normalizada' (instituída e estabilizada), é percibida e interiorizada como natural, e, xa que logo, non suxeita a cuestionamento. Pero cando non existe tal tradición (ou non está dabondo fixada e institucionalizada), cada produtor dun texto escrito ten que resolver por si mesmo a tarefa de segmentación do continuo oral, tarefa altamente sofisticada e que presenta numerosos problemas que — contra o que poida parecer a primeira vista — non sempre son de solución doada (véxase ilustración de problemas deste tipo nos textos rosalianos no apéndice 1). Por iso nós, os lectores e lectoras actuais, amestrados nunha determinada análise gráfica da lingua que se nos deu feita e por tanto nos parece lóxica e evidente, temos que facer un esforzo de empatía para pórmonos no lugar dos primeiros cultivadores do galego, sendo este un idioma practicamente ágrafo no que eles, forzosamente, eran case (ou sen case) analfabetos. Mesmo máis tarde, cando comeza a existir un repertorio de escritos en galego relativamente abundante, os problemas persisten, por superabundancia de variación ou, o que é o mesmo, falta de fixación. Xa que logo, nos textos en galego do período en aprezo observamos o esforzo individual de cada escritor por realizar a devandita tarefa de análise e segmentación da cadea falada nunha chea de aspectos miúdos, como nos mostrará a nosa análise dos textos rosalianos. Para resolver as innúmeras cuestións 
que levantaba este labor, tiñan que estearse nos escritos anteriores ao seu acado e mais nas prescricións dalgúns gramáticos, pero tamén tiñan que pór en xogo a súa intuición lingüística e os seus criterios particulares.

Convirá lembrar aquí o que antes dixemos acerca da poesía como xénero ponte ou de transición entre a fala e a escrita: no século XIX, o poema (ou determinado xénero de poemas) está concibido como un texto oral, e por iso o oído desempeña un papel moi importante, máis importante ca o ollo, na súa composición. Ora, por este mesmo carácter fronteirizo entre os dous rexistros, a poesía non é o medio idóneo (polo menos, non é tan propicio coma a prosa) para atinxir a autonomía do discurso escrito, e, en particular, realizar a segmentación do continuo oral e fixar a ortografía. Tal como explicamos anteriormente, o poeta tende a estar máis atento ao son da lingua, e ademais está lexitimado para explorar os múltiples recursos que lle ofrece a variación lingüística con moita máis liberdade ca o prosista (niso consisten as 'licenzas poéticas'). En particular, por causa dos padróns métricos, rítmicos e rimáticos aos que debe aterse, o versificador pode xogar con licenzas fónicas que o prosista ten practicamente vedadas, mentres que precisamente a fixación do código de escrita pasa por acoutar drasticamente esas licenzas e xerarquizar aquela variación, limitando as súas marxes e reducíndoa ao funcionalmente rendible.

Polas razóns que máis adiante se verán, no noso estudo consideramos pertinente distinguir como procesos distintos o de produción dos textos manuscritos e o de reprodución mecánica ou tipográfica (isto é, de edición) destes. O primeiro consiste na xeración do texto escrito mediante a transposición da voz en letra, isto é, mediante a conversión dunha cadea sonora en secuencia escrita. Isto pode parecer banal, pero non o é: a maior parte dos textos escritos son producidos e recibidos mentalmente, sen referencia á oralidade, isto é, sen traducilos ao oído nin pensar 'como soan'. Consideramos que esta observación é fundamental, por canto dá a clave para descodificar aspectos fulcrais dos textos rosalianos. A reprodución tipográfica destes, co obxectivo de conseguir a súa difusión, presenta uns condicionantes diferentes, en primeiro lugar porque implica a revisión dun texto xa escrito, e en segundo lugar porque depende da intervención de mans alleas á propia autora e de convencións, criterios ou incluso marcos normativos alleos a esta. O estudo dos primeiros textos poéticos en galego de Rosalía ilustra abundantemente o devandito, como decontado mostramos. 


\section{A PRIMEIRA ESCRITA ROSALIANA EN GALEGO: INVENTARIO E CORPUS TEXTUAL ${ }^{3}$}

Cando nos enfrontamos ao noso tema, a primeira pregunta que temos que resolver é: como escribía a propia Rosalía en galego? A seguir, veñen as preguntas sobre as determinacións, circunstancias e motivacións que axudan a entender as características da súa escrita. Ora, para respondermos acaidamente á primeira pregunta, cómpre realizarmos unha coidadosa análise comparativa (e, se é o caso, cotexo), dos manuscritos autógrafos e das edicións dos seus textos que verosimilmente se atopan máis próximas a estes. A clave debían dárnola os primeiros, pero, infelizmente, por razóns que son ben coñecidas ${ }^{4}$, dispoñemos de moi contados manuscritos autógrafos seus, que, realmente, son escasísimos para a produción en galego. Que saibamos, os estudosos actuais só tivemos acceso a tres manuscritos (ou grupos de manuscritos) en galego de Rosalía reputados como autógrafos:

1. O primeiro grupo comprende dous autógrafos indubitados que publica Juan Naya nos Inéditos de Rosalía 5 . Son de importancia capital, por estaren reproducidos en facsímile, a composición «Tes un-ha frente d'Apolo» (idem, 28-29), que forma parte dun feixe de papeis doados ao Concello da Coruña polas fillas [autógrafo núm. 1], e o tetrástico «Aquí vexo os cans y os seus amigos» (idem, 63) [autógrafo núm. 2]. O primeiro é un poema de extensión reducida, o segundo constitúe un texto extremadamente breve.

3 Toda a sección e mencións do presente traballo referidas a textos autógrafos en galego de Rosalía de Castro deben ser revisadas á luz das nosas pescudas e achados realizados con posterioridade a abril de 2013; nalgún caso, inserimos notas aclaratorias. Temos en preparación, para a súa publicación e difusión pola Real Academia Galega, un estudo que recolle a totalidade de autógrafos poéticos da autora, en galego e castelán, que se atopan actualmente accesibles en arquivos públicos e fondos privados. A análise deste material obriga a matizar algunhas afirmacións contidas no presente traballo, pero confirma no substancial as observacións e conclusións a que chegamos. Véxase tamén Monteagudo, Henrique / Lama, María Xesús, Manuscritos poéticos inéditos de Rosalía de Castro, dispoñible en rede no espazo web da RAG: http:// www.realacademiagalega.org/documents/10157/24863/IneditosPoeticos-RdC-RAG.pdf?version=1.0.

4 A vontade da propia autora de que fosen destruídos, cumprida escrupulosamente polas súas fillas Alejandra e Aura; e máis tarde a decisión de Murguía de destruír as cartas da poeta (Naya 1953, 18-19). Finalmente, as decisións de Juan Naya e os seus herdeiros, que acabaron por dispersar os poucos que restaban ou incluso subtraelos ao escrutinio dos investigadores.

5 Véxase Naya 1953, 15-16, onde explica como chegaron ás súas mans. 
2. O segundo grupo fórmano outros textos a que o mesmo Juan Naya se refire na devandita obra, dándoos tamén como autógrafos e ofrecendo edición parcial deles (1953, 67-74). Primeiro menciona un prego que recolle o romance «Las Tres Comadres» e unha versión do «Pai noso» en galego, mais unha páxina que titula "Romances y cantares», onde copia unha canción de Nadal, que o editor reproduce modernizando a grafía («aquí las aliviamos de sus faltas ortográficas»), o romance «La Virgen se está peinando» e mais unha canción popular, que tamén reproduce, seguindo o mesmo criterio modernizador. Canto a nós, estes autógrafos son hoxe inaccesibles. Despois fala dunha 'nota' que encabeza 'Lestrobe', composición da que reproduce un tetrástico. A seguir este estudoso fala sen moita precisión de 'catro pregos' que conteñen cantares populares acompańados dalgunhas notas. Dun deles reproduce tres trísticos e unha nota de Rosalía. Doutro reproduce un trístico máis, e por último edita un romance que cantaban os cegos perante a Porta Santa da catedral compostelá.

Pola nosa banda, conseguimos acceder directamente a un folio e unha cuartilla dos devanditos, grazas a que un deles obra actualmente no arquivo da RAG («Lestrobe») e o outro na Fundación Penzol («Estrelińa do luceiro»). Advertimos que «Lestrobe» nos ofrece serias dúbidas canto ao seu carácter autógrafo, polo que decidimos non telo en conta, mentres que «Estrelińa do luceiro" [autógrafo núm. 3a] está escrito cunha letra moi distinta á doutros manuscritos rosalianos indubitados, ben que a diferenza na grafía pode ser explicable pola evolución, co paso dos anos, da forma da letra e mais polo carácter cursivo da letra, comparada co máis califráfico dos autógrafos precita$\operatorname{dos}^{6}$. Ultimamente, tivemos acceso a outro texto desta serie, que, entre outras, recolle a copla «Adios rios, adios montes!» [autógrafo núm. 3b].

3. Por fin, Ricardo Carballo Calero tivo a oportunidade de cońecer e editar outro autógrafo rosaliano, que el considera indubitado 7 . O saudoso profesor asegura que consultou este autógrafo no Arquivo da Real Academia Galega,

6 Actualmente, temos a certeza de que tanto «Lestrobe» canto «Estreliña do luceiro» son autógrafos rosalianos [Nota do autor].

7 O traballo fora publicado inicialmente en Carballo 1967, despois foi reproducido en Carballo 1979, 14851. [Nota do autor: O orixinal atópase na Fundación Rosalía de Castro e é indubidablemente autógrafo]. 
pero a nós non nos foi posible localizalo alí, probablemente porque obraba en poder de Juan Naya. Aínda que non podemos acceder directamente ao manuscrito, ao menos dispomos dunha coidada edición del (seguimos a versión de Carballo 1967, que nos parece máis fiel ao orixinal ca a de 1979, que presenta lixeiras variantes). Trátase dun fragmento dunha composición publicada postumamente, na terceira edición de Cantares gallegos (1909), que comeza co verso "Compadre, desque un vai vello» (Carballo 1967, 253-54 e 1979, 149; véxase tamén Pociña / López en Castro 1992, LIV-LV e 223-27) [autógrafo núm. 4].

Ofrecemos edición destes textos no apéndice 4. Pasamos agora a considerar textos publicados. Os soltos que se publicaron en vida da autora sitúanse, coidamos, nun primeiro nivel de proximidade aos manuscritos rosalianos. Estes deben ser comparados cos textos recollidos nos volumes que Rosalía deu ao prelo en vida: Cantares gallegos (1ª edición, 1863, 2a edición 1872) e Follas novas (1880). No presente contributo imos limitarnos aos máis antigos, relacionados coa primeira edición de Cantares:

1. «iAdios qu’ eu voume» (Castro 1861), primeiro texto en galego de Rosalía que foi dado ao prelo, e que pouco despois sería incluído en Cantares gallegos como "Adios rios, adios fontes!». Este texto é especialmente interesante, porque foi editado aínda nun par de ocasións en 1862 antes da aparición do libro, no Album de la Caridad, 413-15, e en Galicia. Revista Universal de este Reino núm. 16 (1862), 252-53. Andrés Pociña e Aurora López ofrecen unha reprodución fotográfica do texto da primeira edición (1991, I, 123-25).

2. Os poemas de Rosalía incluídos no Album de la Caridad (AdC): ademais do devandito "Adios», incluíronse outros catro poemas que logo formarían parte de Cantares gallegos (véxase abaixo \$6): «Castilla» (AdC, pp. 423-27, $\mathrm{CG}_{1}$ núm. $25>\mathrm{CG}_{2}$ núm. 27), «O caravel negro» (AdC, p. 761, $\mathrm{CG}_{1}$ núm. 8 $>\mathrm{CG}_{2}$ núm. 10), «A romaria da Barca» (AdC, pp. 771-76, $\mathrm{CG}_{1}$ núm. 5 > $\mathrm{CG}_{2}$ núm. 6) e «iTerra, a miña!» (AdC, pp. 785-89, $\mathrm{CG}_{1}$ núm. $15>\mathrm{CG}_{2}$ núm. 17).

3. "Ó gaiteiro», composición publicada primeiramente no núm. 4 de El Eco Escolar. Revista semanal compostelana, cientifica, literaria y de intereses generales (EE), do 22 de xaneiro de 1863, e inmediatamente despois en Cantares gallegos 
$\left(\mathrm{CG}_{1}, \mathrm{VII}>\mathrm{CG}_{2}, \mathrm{VIII}\right)$. Citamos pola edición que ofrece a compañeira Lydia Fontoira (2011), a quen se debe esta importante noticia.

4. «Xuizo do ano», composición publicada no Calendario Gallego editado por Soto Freire en 1863, que foi recuperada e editada co esmero que o caracteriza por Bouza Brey (1968).

Para o conxunto da súa obra, habería que ter en conta, ademais ${ }^{8}$ :

5. As traducións ao galego de poemas de Ventura Ruiz Aguilera publicadas en 1864-65: unha serie de 'cantares' estampados en El Museo Universal (MU) en 1864-65 (véxase Rosa 1958, 229-34 e mais Pociña / López en Castro 2003, lxii-iv e reprodución nas pp. 327-51) e a versión do poema "Ruinas», editada pola primeira vez na segunda edición da obra Armonías y cantares (1865), nunha segunda ocasión en Elegías y cantares (1873), ambas de V. Ruiz Aguilera, e aínda posteriormente en El Herado Gallego (1874), antes de aparecer no volume Follas novas (1880) (Monteagudo / Vilavedra en Castro 1993, 413-18).

8 Outras composicións de Rosalía, ben que fosen impresas en vida fóra dos seus dous volumes de poesía en galego, ben que fosen incluídas en edicións póstumas das súas obras, ou ben dadas a estampa de xeito independente, teñen tamén interese a título de comparanza: ademais das xa indicadas —entre outros, nos poemas de Cantares gallegos publicados primeiro no Album de la Caridad (véxase máis abaixo), as versións de poemas de Follas novas dadas ao prelo antes de que esta obra vińese a lume (Monteagudo / Vilavedra en Castro 1993, 18-25)—, pensamos en textos como o poema «De Galicia os cimeterios», de que foi publicado un fragmento en La Patria Gallega en 1891 e que logo impreso ao completo en 1917 en La Temporada de Mondariz baixo o título «Unha boda na aldea» (Filgueira 1967), o que comeza "Ora detente, estranxeiro", tamén publicado por La Temporada de Mondariz en 1917 (Taibo 1948) ou os textos incluídos na edición de 1909 das Obras completas, ao coidado de Manuel Murguía (Pociña / López en Castro 1992, XXXII e 219-27 e Castro 2003, XXXIV-XXXV e 299-351).

9 De todos os xeitos, temos testemuño directo da intervención editorial de mans alleas nas versións destes textos publicadas fóra de Galicia. Así, nunha carta do 25 de abril de 1865, Ruiz Aguilera escríbelle a Murguía: «Por el correo de hoy le remitirá a V. Guijarro un ejemplar de Armonías y cantares. Como a pesar de la buena letra en que estaban copiadas las traducciones hechas por Rosalía, se me ofreciesen varias dudas, las consulté con Vidal y Peón; de modo que si ven ustedes alguna variante en tal o cual palabra, no la atribuyan a mí, sino a aquéllos, que guiados por el mejor deseo y del mayor lucimiento de la traducción, corrigieron las pruebas tres o cuatro veces» (Citamos por Rosa 1958, 225). Mesmo así, a edición que ofrece Machado da Rosa das versións galegas dos cantares de Ruiz Aguilera non están exentas de grallas, tal como se pode comprobar comparándoas coa máis coidada edición de Pociña / López. 
6. «Si a vernos, Marica, nantronte viñeras» e "Que ten o mozo?», poemas incluídos na segunda edición de Cantares gallegos $\left(\mathrm{CG}_{2}\right.$, XXXII e XXVII, respectivamente), que apareceron previamente en El Almanaque de Galicia de Soto Freire, o primeiro en 1864 e o segundo en 1868. Estas edicións previas pódense consultar na edición que ofrece a compañeira Lydia Fontoira, a quen debemos a noticia destes textos (2008).

7. O relato inicial da serie "Contos da mińa terra», que quedaría sen continuación e que por tanto acabou sendo único, polo que recibiu o título de Conto gallego (Castro 1864). Coñecemos o texto da primeira edición, estampada en 1864 no xornal coruñés El Avisador e ignorada ata data recente (reproduciuna Ríos Panisse 1995); un exemplar desta é custodiado na Biblioteca da Real Academia Galega, que a ofrece no seu sitio web en reprodución dixital. Aínda máis recentemente, sóubose que existiu unha segunda edición en vida da autora, publicada en 1868 no periódico El Eco Ferrolano (Torres Regueiro 2012). O estudoso que exhumou esta edición promoveu hai pouco a súa reprodución facsímile, que deu ao prelo a Asociación Cultural Eira Vella de Betanzos (Castro 2012; agradecemos cordialmente a este estudoso que nos facilitase un exemplar). A terceira edición, única cońecida ata 1995, apareceu no Almanaque Gallego de 1923 publicado en Bos Aires por M. Castro López; desta deu noticia e reprodución, modernizando a ortografía, Bouza Brey nos Cuadernos de Estudios Gallegos (Bouza Brey 1946) ${ }^{10}$.

8. «Dend'as fartas orelas do Mondego", poema estampado no Almanach das senhoras que se editaba en Lisboa (1884), que foi recuperado e coidadosamente editado tamén por Bouza Brey (1948).

Dado que imos centrar a nosa atención en Cantares gallegos, e particularmente na súa primeira edición, canto a textos impresos fóra de volume, prestaremos especial atención a«iAdios qu’eu voume» (doravante, «Adios»), «Ó Gaiteiro» e os poemas incluídos no Album de la Caridad. No que atinxe a Follas novas, ofrecemos unha primeira aproximación no estudo preliminar da nosa edición de 1993,

10 A edición do "Conto gallego» publicada en 1923 no Almanaque Gallego de Bos Aires (XXIII, 95-104) preséntase como baseada nun manuscrito autógrafo de Rosalía. Este áchase actualmente depositado no arquivo da Real Academia Galega, que nos facilitou unha reprodución dixital. Á vista desta reprodución, coincidimos co antigo arquiveiro da RAG, Juan Naya, en que ese manuscrito é, sen ningunha dúbida, apógrafo. 
na que fixemos un esforzo notable (infrecuente e non sempre recońecido) por ofrecer un texto crítico presentado e fundamentado como é debido (Monteagudo / Vilavedra en Castro 1993, 47-98).

\section{O TESTEMUÑO DOS AUTÓGRAFOS}

Vaiamos agora aos autógrafos. En primeiro lugar, hai que ter en conta que non podemos darlles unha data aproximada, pero tampouco isto é imprescindible para o noso propósito. $\mathrm{O}$ relevante para nós é que, simplemente por comparanza da caligrafía con outros autógrafos rosalianos, podemos ter unha razoable certeza de que os núms. 1 e 2 son bastante anteriores a 1880, o que tamén pode ser o caso do núm. 3b, mentres que o núm. 3a (se é autógrafo, pois existen dúbidas razoables sobre este punto, como veremos) debe ser posterior a esa data. En conxunto, os devanditos textos publicados antes de Cantares ou fóra de volume e mailos autógrafos núm. 1, 2, 3b e 4 confirman algunhas características grafemáticas da escrita rosaliana que xa cońecemos a través das súas obras impresas. Vexamos:

1.- Canto ao inventario alfabético, os textos impresos e o autógrafo núm. 4 testemuñan o uso do dígrafo complexo $<\mathrm{n}$-h $>$ para a nasal velar que aparece en un-ha, algun-ha e ningun-ha. Esta é a grafía que se rexistra na primeira edición de Cantares (matizaremos isto máis adiante) e de Follas e mais nas dúas edicións decimonónicas do Conto gallego, mentres que na segunda edición de Cantares aparece unha, uso este que, por tanto, podemos confirmar que case con toda seguranza non corresponde ao criterio da autora. A grafía $<\mathrm{n}-\mathrm{h}>$ fora adoptada por J. M. Pintos (ao menos, n’A gaita gallega, 1853), mentres que Añón prefería escribir un-a (Bel Ortega 1991); no Album de la Caridad tende a imporse uniformemente a solución que acabaría xeneralizándose, unha, algunha, ningunha. Esta última solución é a que aparece nas versións fóra de volume de «Ó gaiteiro» (1863) e «Que ten o mozo?» (1868). Só o autógrado núm. 3a ofrece <nh>: Cunha chaviña (v. 21). No caso deste último, se realmente é autógrafo, a adopción de $<$ nh> podería explicarse pola evolución dos criterios scriptolingüísticos da autora, como veremos ( $c f r$. apéndice 3).

2.- Representación do alomorfo do artigo sen trazo de unión: $<$ po lo $>$. Nos autógrafos non se rexistra o emprego do guión ou trazo $<->$ para representar o 
alomorfo \{lo\} do artigo determinado: vivol'os (1.11), querela cama (3a.10), po lo veso (3a.16), po lo medio (3b.40), Dio lo pague (4.13), resucital a morte (4.16), po la tema (4.26). Na primeira edición de Cantares a representación con trazo aparece unicamente no prólogo da autora e a partir do cantar núm. 26, onde se emprega sistematicamente: pó-lo, po-lo, po-los, po-la, tóda-las... (véxase sobre isto, Lama en Castro 1995, 94, a táboa 6 do apéndice 2, e o que expoñemos máis adiante \$7). Na versión de «Ó gaiteiro» publicada con anterioridade a Cantares, lemos nunha ocasión $<$ po la $>$ e en cinco <pó la $>$, sempre sen trazo, pero con tendencia a acentuar $<$ pó $>$, mentres que nos propios Cantares, a proporción é inversa: catro ocorrencias de <po la $>$ contra dúas de <pó la $>$; en todo caso, confírmase a non utilización do trazo nese contexto ${ }^{11}$. A representación preferida por Rosalía nos textos precitados é tamén a corrente n’A gaita gallega de Pintos: todo los, po lo, po $l a, . .$. Pola contra, en Follas novas o uso do trazo, adoito en combinación co apóstrofo, é moi abundante (Monteagudo / Vilavedra en Castro 1993, 48, 54, 72-73). Isto débese a unha evolución dos criterios da autora ou ao(s) editor(es) de Follas?

3.- Uso do apóstrofo. Constátase que a utilización do apóstrofo nos autógrafos núm. 1, 2 e 4 coincide co que se rexistra tanto en Cantares (Lama en Castro 1995, 94; véxase máis adiante táboas 2, 3, 4 e 5 do apéndice 2 e \$7) coma en Follas novas (Monteagudo / Vilavedra en Castro 1993, 52-54, 72-74)12: d'apolo (1.1), ll'oin (1.10), qu'asi (1.12), Gustanmos (1.13), m’an (1.14), n’ey (1.17), śalá (2.3), qu'ay (4.5), qu'estamos (4.10)... No 3b, o apóstrofo emprégase con menos frecuencia e nalgúns casos foi inserido nunha revisión posterior á primeira redacción: Qu’o que (3b.33), d’ir (3b.38). No autógrafo núm. 3a prescíndese totalmente deste signo, que podería aparecer en do luceiro (3.1), dame un ay (3.6), atravesalle un codeso (3.14), que un becerro (3.15), Cunha chaviña (3.12), reviraseme o sentido (3.26)... Vemos aquí outra opción gráfica que singulariza este manuscrito. Endebén, nos autógrafos a representación dos encontros de preposicións \{de, en\} co artigo determinado faise directamente, sen botar man de apóstrofos nin tiles: na (1), do, da, das (3a), dos, no (3b), da, dos, no, nos (4). Co artigo indeterminado,

11 En troca, na segunda edición de Cantares, nesa mesma composición aparecen tres formas con trazo: <póla>.

12 Tamén resulta rechamante o contraste entre a versión do poema «Quixente tanto, meniña» de CG1 (VIII) e a de El Museo Universal, estampada un ano máis tarde, pois na segunda obsérvase un maior emprego do apóstrofo: branca aurora / branc'aurora; todo ardente / tod'ardente. 
pronome persoal e indefinidos rexístrase uso do apóstrofo coa preposición \{de\}: d'eles, d'outros (1), d'un (4). No caso da preposición \{con\} rexístrase vacilación: cunha (3a.21), Cas (3b.8), c’o (4.34). Para os textos publicados en 1861-63, véxase o que se di máis adiante $\$ 4$.

4.- Representación da sibilante prepalatal como $<\mathrm{x}\rangle$. O contraste entre as prácticas grafemáticas testemuñadas polo autógrafo núms. 3a e os núm. 1, 2, 3 b e 4 revélase moi notable no tocante á representación da sibilante prepalatal. Lembramos que, a xulgar polos seus poemarios impresos, Rosalía adoptou desde o comezo e de xeito consistente a innovadora solución simplificada ou fonémica, fronte á práctica da maioría dos coetáneos cultivadores literarios do galego, que preferiron a solución etimográfica (sirvan de exemplo os nomes xa antes alegados de Pintos, Añón, Antonio María de la Iglesia e Pondal). Así, na primeira e segunda edicións de Cantares utilízase a representación $\langle\mathrm{x}\rangle$, con escasas vacilacións (Lama en Castro 1995, 92-93), mentres que en Follas novas esa letra leva superposto un signo diacrítico, a diérese. $\mathrm{O}$ autógrafo núm. 2, coa forma vexo, que aparece repetida, confirma que a grafía empregada por Rosalía era precisamente $<\mathrm{x}>$. Quedamos na dúbida sobre se a variante gráfica adoptada en Follas novas, co diacrítico superposto, responde a unha decisión da autora ou do(s) editor(es) do libro. En todo caso, o que chama poderosamente a atención é a opción pola etimografía no autógrafo núm. 3a, que se pon de vulto nas formas Janiño, Jan, quigera, ligeiro. As devanditas discrepancias nas prácticas grafemáticas entre os autógrafos núms. 1, 2 e 4 fronte ao núm. 3a só teñen dúas posibles explicacións alternativas: ou o último non é realmente un autógrafo ou a escritora seguiu nese manuscrito un criterio distinto ao adoitado nalgún momento. Volveremos sobre isto no apéndice 2 .

\section{DA PLUMA AO PRELO (1). "ADIOS QU'EU VOUME» DO MUSEO A CANTARES}

No seu famoso ensaio Los precusores, Murguía relata como vivindo en Madrid, Rosalía se puxo a escribir o poema «Adios qu'eu voume» nun arrouto de repentina inspiración (Martínez Murguía 1885, 185-86). En troques, nun escrito posterior o historiador afirma que a súa dona comezou a escribir en galego en 1857, e que 
deu en compor os poemas que despois farían parte de Cantares gallegos en Madrid a partir de 1859. Estas informacións, especialmente a última, semellan bastante verosímiles (Barreiro 2012, 261-62). Sexa como for, a revelación da Rosalía poeta en galego prodúcese entre os finais de 1861 e os mediados de 1863 (Bouza Brey 1963). En efecto, ata onde sabemos, o primeiro texto en galego que dá ao prelo a nosa autora é o devandito, estampado nunha publicación da capital do estado ( $E l$ Museo Universal, V.47, 24-XI-1861, p. 375). Deseguido, "Adios qu'eu voume» foi reproducido en 1862 na revista Galicia (núm. 3, 15-VIII-1862, pp. 252-53) e nese mesmo ano foi incluído na antoloxía publicada baixo o título «Mosaico poético de nuestros vates gallegos contemporáneos» (pp. 413-15), incluída no volume Album de la Caridad, que recolle as actas e mailas composicións premiadas nos Xogos Florais celebrados na Coruña en 1861. Como é sabido, «Adiós, qu'eu voume» pasou á primeira edición de Cantares gallegos como composición núm. 13 e á segunda como núm. 15. Imos chamar a atención sobre algúns aspectos da grafía deste texto, comparando as solucións das edicións de 1861 (El Museo Universal) e 1863 (Cantares) ${ }^{13}$.

Teremos tamén en conta, para reforzar a comparanza, o outro poema de Cantares do que coñecemos unha edición previa á aparición do libro (agás os incluídos no Album de la Caridad, dos que falaremos decontado): referímonos a "Ó gaiteiro", estampado, como dixemos, en El Eco Escolar, de Santiago, en xaneiro de 1863. Igualmente, mencionaremos cando sexa o caso o «Xuizo do ano» publicado ese mesmo ano.

1. Adopción da solución fonográfica innovadora $<\mathrm{x}>$ (paxariños, igrexiña, deixo, $x a$, lonxe), que contrasta co cru castelanismo virgen (corrixido para virxe en Cantares). Opción confirmada polos autógrafos núms. 2, 3b e 4. O mesmo por todos os outros textos, incluíndo o máis tardío, «Dend'as fartas orelas do

13 Resumimos as principais variantes entre a edición de 1861 e a de 1863: criei > criey, hortiña > ortiña, prantei > prantey, dos castañares $>$ d'os c., do lugar > d'o l., das silveiras $>$ d'as s., daba á ó meu amor > dab'ó m. a., sempre adios > sempr'a., conozo > conoço, probe e > prob'e, Que hasta > Qu'hastra, aldea que tanto amei $>$ hortiña q. t. a., do meu lar > dó m. l., Erviñas > Herbiñas, virgen > virxe, lébovos nó corazon > lévobos no coraçon, Xa s'oyen lonxe as campanas $>X a$ s'oyen lonxe, mais lonxe, quisais $>$ quizais, desd'orrilliña > desd'á veiriña, non me olvides > non molvides. 
Mondego», especialmente significativo neste punto, xa que foi destinado a unha revista portuguesa.

2. Emprego do $<y>$ para representar o iode epentético (oyen, soyo) e ocasionalmente a semivogal: ay!. No «Gaiteiro» só se rexistra un caso, que corresponde ao alomorfo da conxunción: $Y$ el. No «Xuizo do ano» o uso é abundante, sexa para a semivogal en final de palabra, sexa para a conxunción: hay, $y$ as cunchas, y as dos peliños, y un moño... Na versión de "Adiós» en Cantares, o $<y>$ emprégase de xeito case sistemático para a semivogal en final absoluto de palabra: criey, prantey, pay, biquey, moy (aínda que tamén se rexistran amei, prantei). Este segundo é o uso máis propio de Rosalía. Así, os autógrafos testemuñan $<\mathrm{y}>$ para a semivogal (núm. 1: ey; núm. 3a: ay, nay, oyo; núm. 3b: tocay; núm. 4: ay, fay) e para o alomorfo da conxunción \{e\} (núm. 1, 2 e 3: $Y$ uns ollos; $y$ os seus amigos; $y$ un sapateiro). Por tanto, é probable que para a edición de "Adiós» en El Museo Universal o texto fose suxeito a unha revisión de man allea á da propia autora.

3. Na versión de «dios» de 1861, os encontros da preposición \{de\} co artigo determinado son representados directamente: do meu contento, dos castañares, do lugar, das silveiras, do meu lar, do cabañar, do camposanto, do pomar, do mar. Con $\{\mathrm{en}\}$ só hai un caso, que aparece con til: nó corazon. Coa preposición \{a\} temos: á ó meu amor, O que naceu, á terra. Pola contra, en Cantares o primeiro encontro aparece representado con apóstrofo cando o artigo está en plural, mentres que cando é singular, ocasionalmente leva un til: d'os castañares, dó lugar, d'as silveiras, dó meu lar, do cabañar, do camposanto, do pomar, do mar (véxase máis adiante $\$ 7$, en pormenor). Con $\{e n\}$ a representación é directa: no coraçon. Con $\{a\}$ aparece a representación directa: ó meu amor. Finalmente, coa preposición \{por\} non se utiliza o trazo en ningunha das dúas edicións: pó lo mar. O devandito é congruente coas solucións que ofrece «Ó Gaiteiro»: da romeria, da miña gaitiña; nas siudades, na gaita, Nas festas $>$ Nás festas, nas fiadas; ó meu tocar (=ao); pó la / po la. Igualmente co "Xuizo do ano»: o son (= ó son), as vaquiñas (= ás), os carneiros (=ós); do, dos; na, nos, nas. Xa sinalamos antes tamén nos autógrafos a solución máis adoitada é a representación directa. 
4. En «Adios», uso profuso (pero non sistemático) do apóstrofo para sinalar elisións de vogais, xa na edición de El Museo Universal: m'eu, Qu'eu lle daba, antr'ó millo, n'e, qu'amañece, s'enterrou, d'Asuncion, com'un serafin, s'oyen, digoch'este, desd'orrilliña [sic]. En Cantares, o apóstrofo emprégase aínda con maior frecuencia, sen chegar a ser totalmente sistemático: daba á ó meu amor $>$ dab'ó m. a., sempre adios > sempr'adios, probe e mal pecado > prob'e mal pecado, Que hasta > Qu'hastra, non me olvides > non molvides. Algo semellante acontece coas dúas versións do "Gaiteiro»; así, xa na edición de El Eco Escolar abundan os apóstrofos sinalando elisións (antr'os mozos, só tiñan, qu'as cercaban, c'as iba queimar > qu'as iba queimar, d'amores), tamén no caso de encontro das preposicións $\{$ de\} co artigo indeterminado ou o pronome persoal (d'un-ha figueira) ou da preposición \{con\} do demostrativo (c'aquel), pero non co artigo determinado: Có tambor, ca gaita. En Cantares increméntase moito máis o recurso ao apóstrofo: coma un principe > com’un p., costume en cantar > costum'en c., de engañar > d'engañar, se acompañaba > s'acompasaba, xunta del $>$ xunta d'el, (ven soupera>) qu'el soupera, deranlle o seu pensamento > deranll'ó seu p., cando as veu > cand'as veu; c'a gaita. O incremento do uso do apóstrofo pode deberse á intervención dos editores ou a unha mudanza de criterios da autora, xa que nos autógrafos comprobamos que ás veces este signo é inserido non na primeira redacción, senón nunha versión posterior. A isto segundo parece apuntar «O xuizo do ano», no que abunda o emprego de apóstrofo. Concretamente, para os encontros de preposición \{con\} con artigo, demostrativo ou indefinido, rexístrase: cóa, c’a, ca, cos; nun, nestes, n’outros.

5. Acentuación dos vocábulos monolíteros, en particular os artigos determinados $o$, á e a preposición $a$, práctica herdada do castelán e que en galego é unha fonte de confusións: ó vento, ó dia, á terra, á veiga / os meus sudores, as campanas; nótese coa preposición a: á ó meu amor; á terra. Esta práctica non se verifica nos autógrafos núm. 1, 2 e 4, onde lemos: a moitos, o mesmo (núm. 1), a sua casa (núm. 2), E a mais, $O$ que, E que, E a gorxa, a sede, o calleiro, $e$ forte (=é), a morte, o qu'eu... (núm. 4). No autógrafo núm. 3a o máis frecuente é a acentuación, pero non é sistemática: ó sono, à ela, o teique, o sentido, ó pe... No 3b, a acentuación é ocasional: Si ó queres, pero o meu corason, si ti o matas, ... No «Gaiteiro» tenden a acentuarse, pero non se atinxe a sistematicidade: $e$ / É, opirmeiro, ó tiñan, á todas, A luz, ó seu pensamento (= o). Tamén se rexistra 
abundantemente no "Xuízo do ano»: é frautas, ó tamborileiro, fagan ó compas á un tempo...

6. Seseo esporádico en "Adios»: quisais, pero nacin, corazon e conozo. Nos autógrafos non se rexistran casos, excepto en 3b: corason, sapateiro. $\mathrm{O}$ seseo increméntase en Cantares: conozo > conoço, corazon > coraçon. En troques, paradoxalmente, quisais é corrixido para quizais. No "Gaiteiro», o único caso de seseo que aparece na edición de El Eco Escolar, siudades, é corrixido en Cantares: ciudades.

7. En «Adios» non se rexistran exemplos de $<\mathrm{n}-\mathrm{h}>$, pois non aparecen $u n-h a$, algun-ha, ningun- $h a$; no «Gaiteiro» aparece un-ha. No "Xuizo do ano" non hai exemplos.

\section{DA PLUMA AO PRELO (2). DO ALBUM DE LA CARIDAD A CAN- TARES}

Como dixemos atrás $\$ 2$, no Album de la Caridad, ademais de «Adios», incluíronse outros catro poemas que formarían parte de Cantares gallegos: "Castilla» ( $\mathrm{CG}_{1}$ núm. $25>\mathrm{CG}_{2}$ núm. 27), «O caravel negro» $\left(\mathrm{CG}_{1}\right.$ núm. $8>\mathrm{CG}_{2}$ núm. 10), «A romaria da Barca» $\left(\mathrm{CG}_{1}\right.$ núm. $5>\mathrm{CG}_{2}$ núm. 6) e «iTerra, a miña!» $\left(\mathrm{CG}_{1}\right.$ núm. $15>\mathrm{CG}_{2}$ núm. 17). Ora, que nos revela o cotexo das versións destes textos do Album e Cantares? Inicialmente, un aspecto sorprendente, que non ten relevancia directa para o noso asunto: unha certa auto(?)censura, que tende a limar arestas potencialmente conflitivas de dous poemas. Así, a primeira versión de«iAdios qu’eu voume!» contén unha estrofa que expresa unha contundente crítica social, suprimida nas versións posteriores: «Por xiadas, por calores / Desde qu'amañece ó dia / Dou á terra os meus sudores, / Mais canto esa terra cria / Todo... todo é dos señores». Doutra banda, a primeira versión de «iTerra, a mińa!» contén dous versos, omitidos nas versións posteriores, que rezaban do seguinte xeito: «iAy! morrerei de tristeza, / Soya n'un-ha terra estraña, / Dond'estraña m'alomean, / Donde oyo un falar estraño / Donde oyo unha estraña lengua» (poñemos en cursiva os versos suprimidos).

Volvendo ao noso, o cotexo das versións dos cinco devanditos poemas publicadas no «Mosaico poético» coas estampadas posteriormente en Cantares confir- 
man que as solucións scriptolingüísticas adoptadas por Rosalía respondían a uns criterios propios, conscientes e sostidos á mantenta. Isto ponse de vulto tanto que analicemos as opcións puramente gráficas coma outras con alcance fónico:

1. Como exemplos ilustrativos de solucións puramente gráficas, vallan a xa sinalada adopción da grafía $<\mathrm{n}-\mathrm{h}>$ para unha e a representación do alomorfo $\{-10\}$ do artigo: mentres que A. de la Iglesia prefería a solución máis simple $<$ nh $>$, Rosalía mantén a súa opción $<$ n-h $>$; en canto que o ántologo-editor emprega o trazo (pol-o, tódal-as), Rosalía prescinde del: pó lo, tódalas.

2. Tocante ás opcións de alcance fónico, pensamos principalmente na representación do seseo. Nos poemas que foran publicados no Album en versión 'normalizada' por Antonio de la Iglesia e despois incluídos en Cantares gallegos, Rosalía mantén formas como sintas (corrixido por A. de la Iglesia a cintas), maxesa (<majeza), relosen (<relocen), aderesos (< aderezos), nobresa (<nobreza), llanesa (<llaneza), desir (<decir), asucenas (<azucenas), relose (<reloce), sarandea (<zarandea), sirigüelas (<cirigüelas), embarcaçon (<embarcazon), adoraçon (<adorazon), espaço (< espazo) $\left[\mathrm{CG}_{1}\right.$ núm. $5>\mathrm{CG}_{2}$ núm. 6]; conoço (<conoso) $\left[\mathrm{CG}_{1}\right.$ núm. $13>\mathrm{CG}_{2}$ núm. 15]; quisais (<quizais), conesan (<conezan), sireixa (<sereija) [CG 1 núm. $15>\mathrm{CG}_{2}$ núm. 17]; doçuras (<dosuras), aborreço (<aborrezo), despreços (<desprezos), peçoñosas (<pezoñosas) $\left[\mathrm{CG}_{1}\right.$ núm. $25>$ $\mathrm{CG}_{2}$ núm. 28]. A nosa autora reafírmase nos seus criterios noutros diversos puntos, como o uso dos apóstrofos para sinalar elisións vocálicas (uso presente, pero moito máis restrinxido, nas versións arranxadas por A. de la Iglesia) ou a súa neta preferencia pola variante augua, corrixida por A. de la Iglesia ora a auga ora a ágoa.

3. Pero queremos chamar a atención sobre a solución, $<x>$, que, como dixemos, resulta ser unha innovación que contrariaba a práctica máis común do seu tempo, xa que daquela se daba preferencia pola solución etimográfica. Semella claro que a adhesión de Rosalía á solución fonográfica foi deliberada e incluso cun punto belixerante, feito este en que non se reparou debidamente nin se valorou na súa significación. Testemuño do dito é o que acontece cos cinco poemas en aprezo, a que o editor, Antonio María de la Iglesia, aplicou rigorosamente os seus criterios lingüísticos, o que implicou, entre outras cousas, a 'corrección' das formas fonográficas polas etimográficas: xente > gente, 
xuntados $>$ juntados, lixeiras $>$ ligeiras, refaixo $>$ refaijo, sireixa $>$ sireija, Virxe $>$ Virge, ruxe $>$ ruge, Laxe $>$ Lage, lonxe $>$ longe, xenio $>$ genio, ygrexa $>$ igreja, Rianxo $>$ Rianjo, Rianxeiras $>$ Rianjeiras, $x a>j a$, xardin $>$ jardin... (a A. de la Iglesia escápaselle algún vocábulo: vexan, vexo). Pois ben, en Cantares gallegos todos estes textos manteñen a solución fonográfica orixinalmente adoptada pola autora. E isto a pesar de que, ao menos nun caso, parece que Rosalía puido reutilizar a versión impresa do texto publicado no Album: isto daría conta do feito, doutro xeito difícil de explicar, de que en "Castellanos de Castilla» ( $\mathrm{CG}_{1}$ núm. 25 < AdC «Castilla») remanezan, illadas, as variantes gráficas longe (v. 66), ja (v. 96) e gemendo (v. 104), formas que foron corrixidas na segunda edición de Cantares, restituíndo o $<\mathrm{x}>$, mentres que Ja / ja (vv. 22 e 100) foron recorrexidos para $X a / x a^{14}$. Tornaremos sobre isto no apéndice 2.

Que autor ou autores puideron influír na preferencia de Rosalía por determinadas opcións scriptolingüísticas, en particular pola solución fonográfica $<x>$, un tanto a contracorrente da tendencia dominante no seu tempo? Aínda que este é asunto que habería que debullar máis polo miúdo, coidamos que un dos candidatos máis cualificados para servir de modelo á nosa autora é o poeta Alberto Camino Sigüer (1820-61), a quen se debe un poema celebradísimo no seu tempo, «O desconsolo». Non hai máis ca lembrar o entusiasmo con que Murguía se refire a este autor no seu artigo «Poesía gallega contemporánea», onde incluso reproduce íntegro o seu poema «Nai chorosa» (Murguía 1858). Non por casualidade, Ricardo Carballo xulga Alberto Camino «un craro precusor de Rosalía», en particular, aínda que non unicamente, "polo bo gosto da súa linguaxe» (Carballo Calero 1981, 90). Camino adoptou o <x> (Dobarro 1991, 444) e representou graficamente, de xeito asistemático, o seseo.

Doutra banda, é interesante notar que na transcrición dos cantares populares que Murguía cita no devandito artigo (entre eles, a copla «Aires, airiños, aires»), tamén el emprega o $<\mathrm{x}>(x a$, beixiño, Maruxiña, abaixo, baixo), ao igual que

14 Nos casos doutros vocábulos que aparecen de tanto en tanto nos poemas de Cantares, como gentilesa, en jamás e majo, que manteñen esas formas gráficas na segunda edición, concordamos con M. X. Lama en que debe tratarse de castelanismos. Todos estes datos aboan a hipótese de que a opción de Rosalía pola innovadora grafía fonémica, ou, dito doutro xeito, o rexeitamento da tradicional etimografía, era deliberada e firme. Canto ao autógrafo 3a, remitimos á discusión no apéndice 1. 
outros trazos da escrita rosaliana: pó la, pó lo, dir (= d’ir, esta mesma forma, corrixida, aparece nun dos autógrafos rosalianos, véxase apéndice 4), no, d'esas, qu'eu (o uso do apóstrofo é, así e todo, moi comedido). Este feito ten especial relevancia, se temos en conta que cando nese artigo se reproducen textos doutros autores (nomeadamente, de Pintos e Añón), estes aparecen coa súa propia veste gráfica, aparentemente sen unha intervención correctora de Murguía. Este tamén transcribe a copla "Cantan os galos para o dia», que aparece como epígrafe que motiva o poema núm. 4 de Cantares: pois ben, incluso nun texto tan reducido coma este se rexistran variantes significativas entre o texto dese artigo e o de Cantares, no senso dun progresivo incremento do uso do apóstrofo: pra o dia (Murguía) > pr'ó dia (CG), me hei dir (Murguía) > m’ei d’ir (CG).

\section{SOBRE O PROCESO DE PRODUCIÓN DE CANTARES GALLEGOS}

Como é sabido, Murguía deixou dous relatos parcialmente diferentes do proceso de creación e publicación de Cantares gallegos, en particular —o que nos interesa especialmente-, sobre o papel de Rosalía e del mesmo na edición da obra. En Los Precursores asegura:

Impreso el primer pliego de los Cantares, sin que de ello tuviese noticia, viose obligada á escribir el resto del libro á medida que las cajas demandaban original. Aprisa, sin dar tiempo a que se secasen las cuartillas, sin corregir ni leer al dia siguiente lo escrito la víspera, fecunda, abundante, espontánea sobre toda ponderación, fue dando hoy una, mañana otra, la mayor parte de las composiciones que forman parte de aquel volumen (Murguía 1886, 187-88).

Anos máis tarde escribiu unha versión diferente, que permaneceu inédita ata que foi exhumada postumamente por Juan Naya:

[Aproximadamente partir de 1859, Rosalía...] en sus momentos de descanso fue escribiendo las composiciones que aparecen en sus Cantares Gallegos, los cuales, sin que ella lo supiera, llevé a Vigo y dí a la imprenta de mi buen amigo Juan Compañel. De esto nada supo mi esposa, hasta que terminada la impresión del libro se lo envié para que 
me remitiese el prólogo. Negóse a ello, empeñada en que era mejor saliese el libro con mi nombre y pasó un mes largo sin que se rindiera, hasta que al fin los gastos hechos la obligaron (citamos por Barreiro 2012, 261-62).

Nos relatos fálase de dous asuntos diferentes: a composición dos poemas e a publicación de Cantares. Canto á composición dos poemas, a segunda versión, segundo a cal Rosalía foi compońendo os textos aos poucos, durante un período máis ou menos longo (meses ou anos), é a máis verosímil, aínda que puido acontecer que unha boa parte das composicións de Cantares fosen producidas nos meses previos á publicación do libro e incluso varias delas fosen escritas durante o proceso de impresión deste. A favor desta hipótese apunta o feito de que, como sabemos, non menos de seis poemas de Cantares foron dados ao prelo nos dous anos anteriores á súa vinda a lume, un deles en 1861 en El Museo Universal («Adiós qu’eu voume!»), este mesmo poema e catro máis en 1862 no Album de la Caridad (xa o vimos antes $\$ 2$ ) e, finalmente, outro máis, «Ó gaiteiro», en xaneiro de 1863, na revista compostelá El Eco Escolar (Fontoira 2011, 170). Cando se estampa este último poema, na dita revista indícase que forma parte «del libro de los Cantares populares de Galicia», o cal significa que nese momento o proxecto xa debía estar bastante avanzado. De feito, na cuberta dunha das entregas do Diccionario de escritores gallegos de Murguía que leva data de 1862, pero en realidade foi probablemente impresa en 1863 (a data exacta non é doada de precisar ${ }^{15}$ ), anúnciase

«Cantares gallegos, por Rosalía Castro de Murguía. En prensa este notable libro cuyo interés es tan alto y en el cual se glosan con la mayor sencillez, propiedad y poesía los Cantares populares gallegos, se remitirá a los señores suscriptores tan pronto esté concluida su impresión» (apud Fontoira 2011, 171).

15 A noticia deste anuncio deuna Bouza Brey (1963). Fontoira $(2013,170-71)$ pon de relevo as dúbidas que ofrece a datación en 1862. Por lóxica, supońemos que como cedo o anuncio é de finais dese ano, pero máis verosimilmente será dos comezos de 1863 . O Diccionario de Murguía aparece anunciado na mesma revista a comezos de xaneiro de 1863 (Fontoira 2011, 168). 
No número 45 de El Eco Escolar, do 21 de marzo de 1863, publicítase tamén a obra co título definitivo, mediante un anuncio que se reiterará no seguinte número:

«Cantares gallegos. Versos de Rosalía Castro de Murguia. En prensa esta preciosa colección de poesias gallegas, que tan benevolamente fueron apreciadas por los periódicos de Galicia y Castilla, se anuncia al público para que los que gusten de adquirir tan notable libro, se sirvan avisarlo á su editor, J. Compañel, Vigo; pues no se tirarán mas ejemplares que los necesarios para cubrir los pedidos. Los Cantares Gallegos formarán un precioso volúmen en $8^{\circ}$ francés, de cerca de 309 páginas, esce[1]ente papel, letra compacta, pero clara y elegante» (apud Fontoira 2011, 165).

O primeiro que poñen de vulto estes anuncios é que Rosalía non podía ignorar, como afirma Murguía, que o libro estaba a imprentarse. Ao menos, desde xaneiro de 1863, cando se estampa «Ó gaiteiro»—composición con que se inicia o prego terceiro de Cantares - en El Eco Escolar, acompañado do anuncio da obra, tińa que sabelo. Ademais, se reparamos na progresiva concreción da información, concluiremos que o anuncio na cuberta do Diccionario debeu de ser o primeiro en aparecer (finais de 1862?), o que acompaña a «Ó gaiteiro» debeu de ser o segundo (22 de xaneiro de 1863; nel indícase que «forma un precioso volumen en $8^{\circ}$ francés, letra compacta y clara y papel satinado») e o que acabamos de reproducir, do 21 de marzo, o terceiro, pois aí xa se indica número de páxinas. Nese momento, a impresión debía estar concluída. Se temos en conta que Rosalía asina a dedicatoria o 17 de maio, concluiremos que entre finais de marzo e mediados de maio debeu de transcorrer ese «mes largo» que, segundo a segunda versión do relato de Murguía, a autora se resistiu a escribir o prólogo.

Doutra banda, deste último anuncio temos que deducir, entre outras cousas, que cando aparece Cantares gallegos foran previamente editados non só os dous ou seis poemas (segundo contemos só publicacións periódicas ou tamén o volume Album de la Caridad) dos que hoxe temos noticia, senón algúns — quizais bastantes - máis. Un mellor coñecemento da prensa periódica da época (moita, seguramente, perdida, pero algunha se cadra só extraviada) podería depararnos máis casos de publicación de poemas de Cantares previa á aparición do libro. En todo caso, o que é de todo punto inverosímil é que Rosalía lle propuxese a Mur- 
guía que publicase o libro a nome deste, o cal sería absurdo tendo en conta que contiña non menos de media ducia de poemas que foran publicados a nome da súa autora verdadeira.

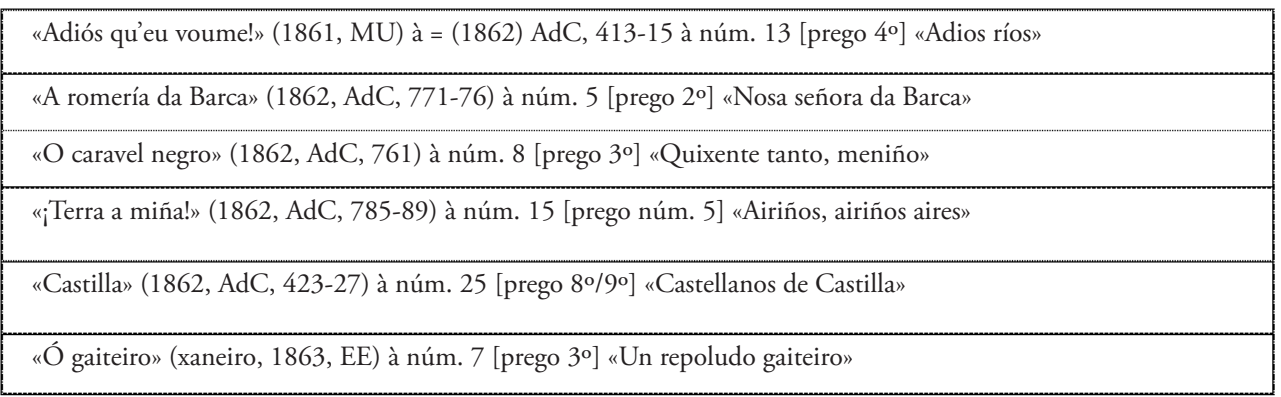

Outro aspecto do devandito anuncio sobre o que queremos chamar a atención é a información verbo da extensión da obra: dise que terá por volta de 309 páxinas, sendo que o libro que aparece pouco despois ten 204 páxinas $(16+190$; véxase abaixo). Este dato resulta aínda máis intrigante cando o comparamos co que a propia Rosalía ofrece no limiar de Follas novas, asinado o 30 de marzo de 1880. Referíndose a Cantares gallegos, a súa autora asegura que «Un libro de trescentas páxinas escrito n'o doce dialecto d'o pais, era n'aquel estonces cousa nova» (Castro 1880, XXVIII). Non parece quedar moito espazo para a dúbida: Cantares gallegos chegou a ter, nalgún momento anterior á súa publicación, aquelas trescentas páxinas. Neste sentido haberá que intrepretar o feito desconcertante de que, despois do prólogo da autora e inmediatamente antes do comezo dos poemas, a primeira edición de Cantares teńa unha portada interior que reza «Primeira parte».

Para conciliar estas informacións contraditorias, ocórresenos que, en efecto, durante a impresión dos pregos de Cantares, Rosalía puido sentirse inspirada, ata compor un número de poemas bastante superior aos trinta e dous finalmente incluídos no volume (puideron chegar aproximadamente a corenta e cinco). A razón de que non todos eles fosen incluídos no libro, que deste xeito quedou con arredor de cen páxinas menos do que se prometía nos anuncios destinados a atraer subscritores, puido ser precisamente que o número de subscricións fose inferior — bastante inferior - ao previsto polo impresor. Nestas circunstancias, 
sería razoable que Juan Compañel preferise limitar a contía do seu investimento, dando a prelo un volume menos extenso do proxectado. Algúns dos textos que quedaron excluídos da primeira edición de Cantares serían recollidos na segunda, de 1872 - probablemente, este sexa o caso dos catro que esta presenta a maiores daquela-, outros xa pasarían a Follas novas, obra esta que, como agora sabemos, estaba practicamente rematada en 1872 . Pero cando se tomou a decisión de incluír en Cantares menos textos dos que Rosalía tiña escritos, fíxose anteceder a colección dunha páxina que a presenta como «Primeira parte», pensando quizais que, se a obra tiña unha boa acollida do público, o resto dos textos poderían publicarse sen moita demora como unha «Segunda parte». É probable que nestas decisións Rosalía non tivese participación, e quizais sexa isto o que evoca Murguía na súa segunda versión do proceso de edición da obra, cando asegura: «De esto nada supo mi esposa, hasta que terminada la impresión del libro se lo envié para que me remitiese el prólogo. Negóse a ello, empeñada en que era mejor saliese el libro con mi nombre y pasó un mes largo sin que se rindiera, hasta que al fin los gastos hechos la obligaron».

En todo caso, a análise da distribución das variantes gráficas a longo de Cantares gallegos pode contribuír a botar un pouco de luz sobre o seu proceso de produción. Iso é o que tentaremos nos parágrafos seguintes.

\section{A VARIACIÓN GRÁFICA DE CANTARES E O PROCESO DE PRO- DUCIÓN DO LIBRO}

Finalmente, Cantares gallegos apareceu con 204 páxinas: o prólogo remata na páxina XIV, segue a portada interior que reza «Pirmeira parte», non numerada, os textos poéticos ocupan as páxinas 1 a 172 (cun erro de impaxinación do texto desta última, que debera ir na 171, que saíu en branco), o glosario vai da páxina 173 á 184; a fe de erratas ocupa as páxinas 185-86, e o índice as 187-88. Destarte, o libro componse de trece pregos, que aparecen numerados a partir do segundo (cantar núm. 4, p. 17); o primeiro prego, que corresponde ás páxinas iniciais da obra, incluíndo o prólogo, non entrou no cómputo, polo que lle atribuímos o número [0]. Deste xeito, a distribución de páxinas e poemas por pregos quedaría así: 
Prego [0] (pp. I-XIV + 2): Cuberta, dedicatoria, prólogo e páxina de título «PRIMEIRA PARTE.»

Prego [1] (pp. 1-16): cantares núm. 1, 2, 3

Prego [2] (pp. 17-32): cantares núm. 4, 5, 6

Prego [3] (pp. 33-48): cantares núm. 7, 8, 9, 10

Prego [4] (pp. 49-64): cantares núm. 11, 12, 13, 14

Prego [5] (pp. 65-80): cantares núm. 15, 16, 17, 18 $\rightarrow$

Prego [6] (pp. 84-96): cantares ß18, 19, 20, 21 $\rightarrow$

Prego [7] (pp. 97-112): cantares ß21, 22, 23 $\rightarrow$

Prego [8] (pp. 113-128): cantares ß23, 24, 25 $\rightarrow$

Prego [9] (pp. 129-144): cantares ß25, LGG, AGG, 26 $\rightarrow$

Prego [10] (pp. 145-160): cantares ß26, 27, 28

Prego [11] (pp. 161-176): cantares 29, 30, 31, Glosario $\rightarrow$

Prego [12] (pp. 177-188): ßGlosario, Erratas notables, Índice

Realizamos unha análise da variación gráfica da obra por pregos, coa finalidade de comprobar se os resultados ofrecían algunha pista relevante (apéndice 2, táboas 2 a 6). O resultado é o seguinte:

1. Variantes que agrupan dunha banda o prego [0] cos finais [7-11], e doutra os demais pregos [1-6].

1.1 Representación do alomorfo $\{$ lo $\}$ do artigo con trazo, $<$ pó-lo $>-<$ polo $>,<$ tóda-las $>$ : [0, 9-11]. No resto do libro, represéntase sen trazo: $<$ po lo $>-<$ pó lo $>,<$ tódalas $>$. Esta segunda representación, sen trazo, é a que se rexistra nos autógrafos e nos textos editados antes de 1863, por tanto, é probable que a introdución do trazo nos pregos 7-11 e 0 sexa debida á intervención dunha man distinta á da autora.

1.2 Representación da contracción da preposición $\{a\}$ co artigo \{o\} con acento circunflexo: $<\hat{\text { ô }}$ (esporadicamente, $<$ ò $>$, con maiúscula $\langle\mathrm{O}>$ ): $[0$, 7-11]. No resto do libro, represéntase <á ó $>$, <á o $>$, <a ó $>$, ou ben $<$ ó $>$, <á $>$, con maiúscula $<\mathrm{A}$ ó $>,<\mathrm{A}$ os $>$, e $<\mathrm{O}>$ (esporadicamente, $<\mathrm{O}>$ ). A representación con $<\hat{\mathrm{O}}>$ non aparece nos autógrafos $(<\mathrm{O}>$, $<$ á $\mathrm{o}>$ ) nin en «Adios» (á 
ó), «O gaiteiro» (<ó >) e «Xuizo do ano» (<0>, <os $>,<$ as $>)$, así que hai que pensar que non se debe a Rosalía.

1.3 Representación con apóstrofe cando a preposición \{con\} se xunta a artigo masculino singular $\left\langle c^{\prime} \mathrm{O}\right\rangle$ (ocasionalmente, $\left\langle\mathrm{c}^{\prime}\right.$ ó $\rangle$ ): [0,7-11]. No resto do libro, $<$ co, có $>$, ocasionalmente, $<$ con o $>$. A primeira grafía $<c^{\prime} o>$ rexístrase nos autógrafos, tal como sinalamos atrás, nos impresos temos $<$ Có> («O gaiteiro», corrixido a < Co> en Cantares) e < cos> («Xuizo do ano»).

1.4 Representación sen apóstrofe e con acento do encontro da preposición \{con\} co artigo feminino singular <cá $>$ (ocasionalmente, $<$ ca $>$, no plural: <cás $>$ ): nos pregos [1-6]; alternando sempre coas outras variantes que aparecen no resto do libro. Nos demais pregos [0,7-11] nunca se rexistra esa representación, e emprégase <có á, c'á> (esporadicamente, <c'a, c’o á>). Nos autógrafos rexístrase $<$ Cas $>$, nos impresos $<$ ca $>$ ( O gaiteiro», corrixido a $<$ c'á $>$ en Cantares), e <co'a $>$, <c'a $>$ e $<$ ca $>$ («Xuizo do ano»).

2. Variantes específicas de series de pregos.

2.1 Representación da consoante nasal velar entre vogais: as variantes $<$ unha>, <ningunha> aparecen unicamente nos pregos [1, 2]; no resto do libro o dígrafo leva trazo: $<$ un-ha $>$, <algun-ha $>$, <ningun-ha $>$. Esta variante parece apuntar á intervención dunha man diferente á de Rosalía.

2.2 Representación da contracción da preposición \{de\} co artigo determinado: as variantes gráficas < dó, dá> están ausentes dos pregos [0, 8-11], mentres que as variantes de tipo <d'os / d'as $>$ son excepcionais nos pregos 1 a 4 (onde a solución preferida é $<$ dos, das $>$ ) e dominantes nos pregos 0 e 5 a 11 (véxase táboa 1). As últimas variantes (<dos, das > son as que se rexistran nos autógrafos e as máis frecuentes nos impresos: en «Adios» dous exemplos de $<$ dos $>$ fronte a un de $<$ d'as $>$, no «Xuizo do ano», $<$ dos $>$. Nin nun nin noutros se rexistran exemplos de <dó, dá $>$. 


\begin{tabular}{|c|c|c|c|c|c|c|c|c|c|c|c|}
\hline $\mathbf{0}$ & $\mathbf{1}$ & $\mathbf{2}$ & $\mathbf{3}$ & $\mathbf{4}$ & $\mathbf{5}$ & $\mathbf{6}$ & $\mathbf{7}$ & $\mathbf{8}$ & $\mathbf{9}$ & $\mathbf{1 0}$ & $\mathbf{1 1}$ \\
\hline po-lo & $\begin{array}{c}\text { po } \\
\text { lo }\end{array}$ & $\begin{array}{c}\text { po } \\
\text { lo }\end{array}$ & po lo & po lo & po lo & po lo & po lo & po lo & po-lo & po-lo & po-lo \\
\hline ô & a o & a o & a o & a o & a o & a o & $\hat{o}$ & $\hat{o}$ & $\hat{o}$ & ó & o \\
\hline do & dó & dó & dó & dó & dó & dó & dó & do & do & do & do \\
\hline d'os & dos & dos & dos & dos & d'os & d'os & d'os & d'os & d'os & d'os & d'os \\
\hline c'ó & có & có & có & có & có & có & c'ó & c'ó & c'ó & c'ó & 'ó \\
\hline có á & cá & cá & cá & cá & cá & cá & có á & có á & có á & có á & có á \\
\hline un-ha & unha & unha & un-ha & un-ha & un-ha & un-ha & un-ha & un-ha & un-ha & un-ha & un-ha \\
\hline
\end{tabular}

Táboa 1. Visión sintética da distribución de variantes gráficas por pregos.

Estes resultados permiten distinguir cando menos dúas fases diferentes no proceso de produción do libro: na primeira arranxáronse os pregos 1 a 6 , na segunda os 7 a 11 e 0 (este, que contén o prólogo, foi o último en comporse e imprimirse); os pregos 5 a 7 poden considerarse, dalgún xeito, de transición. En cada unha destas fases, interviñeron distintas mans na corrección dos textos, ou quizais sexa máis exacto dicir que distintas mans tiveron unha participación diversa en cada fase. É interesante notar que nos pregos 1 a 4, a distribución das composicións faise coincidir coa de pregos, mentres que a partir do prego 4 non se dá tal correspondencia, de xeito que a composición final de cada prego queda inacabada e continúa no prego seguinte (agás o prego núm. 10). Iso pode ser un indicio dunha planificación máis coidadosa da distribución do texto nos comezos da obra, e unha maior improvisación a partir dese prego 4. De feito, os catro primeiros pregos parecen ser os que presentan unha maior fidelidade ás pautas scriptolingüísticas da autora (ata onde podemos xulgar tendo en conta a magreza dos elementos de apoio que posuímos), mentres que os 7 a 11 e 0 parecen presentar unha intervención máis ampla de mans alleas a ela.

A serie inicial de pregos ( 1 a 4 ) forma un grupo ben característico: xa dixemos que dunha banda presentan uns riscos scriptolingüísticos especialmente próximos aos autógrafos e a «Adios» e "Ó gaiteiro», e doutra ofrecen unha distribución especialmente coidada de composicións e pregos. Engadamos agora que nese grupo se concentran a maior parte dos textos rosalianos que vińeran previamente a lume (catro de seis): «Nosa señora da Barca» (núm. 5), «Un repoludo gaiteiro» (núm. 7), «O caravel negro» (núm. 8), «Adios rios, adios fontes» (núm. 13); outro máis encabeza o prego 5 ("Airiños, airiños, aires»). Isto é, Rosalía comezou por botar man de material que xa tińa escrito, o cal quere dicir que a composición 
do libro non foi tan atropelada como suxire Murguía. De todos os xeitos, como se deduce do que levamos dito no presente contributo, queremos subliñar que, malia eses primeiros pregos responderen máis fielmente ca os demais aos criterios scriptolingüísticos da autora, as composicións aí inseridas foron obxecto dunha revisión que implicou numerosas correccións en relación coas versións previamente publicadas. Pero, a diferenza do que ocorreu nos pregos finais do libro, esa revisión estivo en mans fundamentalmente da propia autora.

Agora, dentro dese grupo, os pregos 1 e 2 ofrecen unha peculiaridade que os afasta do conxunto do libro, cal é a representación da consoante nasal velar como $<\mathrm{nh}>$. Pode isto indicar que, en efecto, a composición do libro se puxo en marcha sen contar coa intervención da autora? É unha hipótese, que cadraría en certa maneira correlato de Murguía. Quizais aconteceu que Murguía puxo en marcha a obra de costas a Rosalía, máis adiante conseguiu involucrala no proxecto e, finalmente, por razóns que descoñecemos (quizais unha delas foi que o número de subscricións foi menor do agardado), Rosalía foi desvencellándose do proceso de publicación. Concretamente, é probable que cando a impresión dos pregos 9 , 10, 11, 12 (os dous últimos conteñen o glosario, fe de erratas e índice) e 0 (co prólogo), ela xa non revisase as probas de imprenta.

Neste senso, resulta suxestivo reparar no que acontece co cantar 25 («Castellanos de Castilla», véxase o que se di atrás $\$ 5$ ). Como sabemos, fora imprentado no Album de la Caridad, despois de que o antólogo e editor desta obra, A. de la Iglesia, o sometese a unha coidadosa e profunda revisión ortográfica, na que impuxo a solución etimográfica. Como dixemos, a versión que ofrece Cantares fai caso omiso desas correccións, pero temos motivos para pensar que se utilizou como texto-base o impreso no

Album, probablemente recorrixido da man da autora. Isto explicaría que remanezan grafías como <longe> (v. 66), inéditas na nosa autora. Pois ben, ese cantar ocupa as catro últimas páxinas do prego 8 (páxinas 125-28, co groso da composición) e a primeira do prego 9 (páxina 129, con só as catro últimas estrofas). A variante devandita está aínda no prego 8 (p. 127), pero nas catro estrofas que encabezan o prego 9 (p. 129) detéctanse dous 'erros' máis: Ja (v. 96) e gemendo (v. 104), que contrastan cunha outra corrección ja > xá (v. 100). Diríase que a corrección deste último prego foi máis descoidada. No mesmo sentido, tamén é notable o que acontece co texto da páxina 172 (onde remata o último poema 
do libro), erroneamente impaxinado, pois debía ir na páxina 171, que quedou en branco.

En fin, o presente contributo ofrécese como unha achega ao estudo da variación scriptolingüística da obra en galego de Rosalía, non só polo interese intrínseco que esta ten para a historia da lingua e da escrita, senón vencellado coa análise doutros aspectos da produción e traxectoria da inmortal cantora do Sar. Cumprirá analizar o conxunto da produción en galego da autora para afondar no coñecemento da evolución das súas pautas ortográficas e das prácticas editoriais da época. Deste xeito, tamén teremos mellor fundamento para edicións criteriosas e autenticamente críticas da obra rosaliana. 


\section{APÉNDICE 1}

Neste apéndice imos ofrecer algúns exemplos de representacións escritas que á vista son agramaticais, pero cando son vocalizadas, ao oído soan perfectamente gramaticais. A anomalía 'gráfica' é consecuencia ou ben da falsa segmentación dunha secuencia sonora, ou ben da elisión dun fonema que na secuencia sonora está 'disfrazado', por causa dunha crase ou outro fenómeno fonotáctico.

1. Son raros os exemplos en que están atinxidas varias consoantes: c’ó seus cores verdadeiros $>c o[s]$ seus... (Cantares, 'Prólogo').

2. Son más abundantes os exemplos que atinxen as vogais: - [a] + [a]: Nón-n'atopou > Non-n[a] atopou (FN III.XXI, 14); sorrisa virxinal da primadera / que amar $i$ a ser dichoso-los convida > que [a] amar (FN III.xxv, 18); Pepa, a fertunada Pepa, > [a] afertunada (FN IV.v, 16); Aquel que veu nunca mais que a propia [terra] / a iñorancia o consome $>$ [A] aquel (FN V.i, 58); non chores, non chores / que ausencia envive$c e>$ [a] ausencia (FN V.xII, 11-12); é branca com'azucena $>$ com[a] [a] azucena (FN III.IX, 3); nunca tua sorte terca > nunca [a] tua (FN III.xx, 53). Á luz do anterior, coidamos que se deben reinterpretar as ocorrencias de tipo un alma (CG, XXIII, 17; FN III.xxv, 55; IV.viII, 53...) > unh[a] alma. No mesmo caso se atopa un arpa (FN IV,VIII, 57) $>$ unh[a] arpa.

- $\quad$ - [a] + [o]: sin que ó ver do inocente orfandade / se calma dos ricos / a sede avarenta $>$ [a] orfandade (FN III.XLI, 23).

- $\quad$ - [a] + [e]: o inverno xa pasou y hermosa / primadera vai vir $>$ [a] hermosa (FN III.III, 36).

- - [a] / [o] ? + [o]: Dos desamparados / tendes o menaxen > [a] / [o] homenaxen (FN V.xxvi).

Pero o carácter transitivo da escrita rosaliana non só se pon de manifesto en casos coma os anteriores, senón en exemplos de falsas segmentacións que provocan o desconcerto de quen le (incluídos os editores). Pońamos por caso os versos que na primeira edición de Follas novas rezan «Ouh Torres d'Oeste! / tan soyas e mudas, / c'a vos' atentaches / a miña tristura» (FN V.xxvi, 80). As solucións que se teñen dado van desde "ca vosa atentaches / a mińa tristura» (Carballo Calero, 
AM, Lydia Fontoira) // "cál vós atentaches» $(\mathrm{AH})$ / "ca vós atentaches» (Roig Rechou). Coidamos que a solución correcta é «ca vosa tentaches / a mińa tristura» (HM / DV), isto é, 'coa vosa [tristura], tentastes a miña [tristura]'.

Cando un treito presenta unha combinación de problemas de segmentación enganosa e puntuación ambigua, a súa interpretación pode resultar especialmente complexa:

Pero n'a ven, anque $a ́$ mirada tendan [non ven à a disgracia]

arrededor, para evitaren, cantos

o seu bafo pestífero, n'atopan

n’o espazo nin na terra nin no mare;

anqu'ela en todo está, sempre dañina.

(FN 1a edición; III.xi, 9-13)

Carballo Calero e Fontoira ofrecen a seguinte lectura:

Pero n'a ven, anque a mirada tendan arrededor, para evitaren, cántos, [evitaren à o seu bafo pestifero]

o seu bafo pestífero; n' $[a]$ atopan [non atopan à a disgracia]

n'o espaso nin na terra nin no mare; anqu'ela en todo está, sempre dañina.

Arturo del Hoyo prefire estoutra:

Pero no a ven, anque a mirada tendan arrededor, para evitaren, cautos, o seu bafo pestífero, $\mathrm{n} i[a]$ atopan n’o espaço nin na terra nin no mare; anqu'ela en todo está, sempre dañina.

Andrés Pociña e Aurora López seguen a emenda do anterior, pero a súa lectura segue sen ser satisfactoria: 
Pero n’a ven, anque á mirada tendan

arrededor, para evitaren, cautos,

o seu bafo pestífero; n'atopan

n'o espazo nin na terra nin no mare

anqu'ela en todo está, sempre dañina.

A solución que nós demos é máis sinxela, pois implica unicamente repór un [a] elidido por crase e retocar a puntuación:

Pero n'a ven, anque a mirada tendan arrededor para $[a]$ evitaren, cantos [par' a evitaren à a disgracia]

o seu bafo pestífero n'atopan [non atopan à o seu bafo pestífero no

espazo...]

no espazo nin na terra nin no mare;

anqu'ela en todo está, sempre dañina.

Xa que logo, segundo a lectura que propomos, a interpretación sería:

Suxeito: todos aqueles que (= cantos) non atopan o seu bafo pestífero no espazo...

Verbo principal: non a ven [a desgracia]

Subordinada concesiva 1: por moito que (=aínda que) a mirada tendan arredor para a evitaren [a desgracia]

Subordinada concesiva 2: [e] a pesar de que (=aínda que) ela [a desgracia] está en todo, sempre daniña

A emenda vén autorizada por outros exemplos en que aparece representada a crase do [a] final da preposición cunha vogal que a segue, como nos exemplos seguintes: y anque ganas tiña delas / non tiña par'as pagar (FN IV.ii, 11), par'a outra vida (FN V.xxviii, 24), par'un probe ('Prólogo' a Cantares). 


\section{APÉNDICE 2. VARIACIÓN GRÁFICA EN CANTARES GALLEGOS}

\begin{tabular}{|c|c|c|c|c|c|c|c|c|}
\hline Cantar/Pr. & \multicolumn{2}{|c|}{$d o, d a$} & \multicolumn{2}{|c|}{ dos, das } & $d o ́, d a ́$ & \multicolumn{2}{|c|}{ d'os, d'as } & outros \\
\hline Prólogo / 0 & \multicolumn{2}{|r|}{6} & \multicolumn{2}{|c|}{-} & - & \multicolumn{2}{|c|}{15} & $d^{\prime \prime o ́}(3), d^{\prime} \dot{a}$ \\
\hline $1 / 1^{\circ}$ & \multicolumn{2}{|r|}{13} & \multirow{2}{*}{\multicolumn{2}{|c|}{$\frac{10}{1}$}} & \multirow{2}{*}{$\overline{1}$} & \multicolumn{2}{|c|}{ - } & \multirow{2}{*}{$\begin{array}{l}- \\
-\end{array}$} \\
\hline $2 / 1^{\circ}$ & \multicolumn{2}{|r|}{-} & & & & \multicolumn{2}{|c|}{ - } & \\
\hline $3 / 1^{\circ}$ & 2 & $=19$ & \multicolumn{2}{|r|}{$\frac{1}{=15}$} & $=1$ & 1 & $=1$ & \begin{tabular}{l|l}
$d \dot{s}$ & $=1$
\end{tabular} \\
\hline $4 / 2^{\circ}$ & \multirow{2}{*}{\multicolumn{2}{|c|}{2}} & \multicolumn{2}{|r|}{2} & 1 & \multicolumn{2}{|c|}{ - } & - \\
\hline $5 / 2^{\circ}$ & 9 & & \multicolumn{2}{|r|}{3} & - & & & - \\
\hline $6 / 2^{\circ}$ & - & $=11$ & 1 & $=6$ & \begin{tabular}{l|l}
- & $=1$ \\
\end{tabular} & 1 & $=1$ & \begin{tabular}{l|l}
$d^{\prime} 0$ & $=1$
\end{tabular} \\
\hline $7 / 3^{\circ}$ & & 1 & & - & - & & & - \\
\hline $8 / 3^{\circ}$ & & 3 & & - & - & & & - \\
\hline $9 / 3^{\circ}$ & & 2 & & 3 & - & & & d'ás \\
\hline $10 / 3^{\circ}$ & 1 & $=7$ & 1 & $=4$ & \begin{tabular}{l|l}
1 & $=1$
\end{tabular} & - & $=1$ & dás $=2$ \\
\hline $12 / 4^{\circ}$ & & 2 & & - & - & & & - \\
\hline $13 / 4^{\circ}$ & & 3 & & - & 3 & & & d'ás \\
\hline $14 / 4^{\circ}$ & 6 & $=10$ & 3 & $=3$ & \begin{tabular}{l|l}
3 & $=6$ \\
\end{tabular} & - & $=1$ & \begin{tabular}{l|l}
- & $=1$ \\
\end{tabular} \\
\hline $15 / 5^{\circ}$ & & 1 & & - & 1 & & & - \\
\hline $16 / 5^{\circ}$ & & 7 & & 1 & 1 & & & - \\
\hline $17 / 5^{\circ}$ & & 1 & & 2 & 4 & & & - \\
\hline $18 / 5^{\circ}$ & 11 & $=20$ & 1 & $=4$ & $-1=6$ & - & $=5$ & - \\
\hline $18_{b} / 6^{\circ}$ & & 1 & & - & - & & & \\
\hline $19 / 6^{\circ}$ & & 5 & & 1 & - & & & dás \\
\hline $20 / 6^{\circ}$ & & 1 & & 3 & - & & & - \\
\hline $211_{a} / 6^{\circ}$ & - & $=8$ & - & $=4$ & - & 1 & $=4$ & $=1$ \\
\hline $21_{b} / 7^{\circ}$ & & 5 & & 1 & 1 & & & \\
\hline $22 / 7^{\circ}$ & & 4 & & - & & & & \\
\hline $23_{a} / 7^{\circ}$ & & $=23$ & 2 & $=3$ & $=1$ & 10 & $=17$ & \\
\hline $23_{b} / 8^{o}$ & & 8 & & 1 & 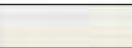 & & & d'o, dás, dos \\
\hline $24 / 8^{\circ}$ & & 6 & & - & - & & & - \\
\hline $25 / 8^{\circ}$ & 3 & $=17$ & - & $=1$ & - & 1 & $=8$ & - \\
\hline$G G / 9^{\circ}$ & & - & & - & - & & & - \\
\hline $26 / 9^{\circ}$ & 3 & $=3$ & & - & - & 1 & $=5$ & $d^{\prime \prime a ́}$ \\
\hline $27 / 10^{\circ}$ & & 1 & & - & - & & 5 & - \\
\hline $28 / 10^{\circ}$ & 3 & $=4$ & & - & - & 1 & $=2$ & d'á, d'o \\
\hline $29 / 11^{\circ}$ & & 2 & & - & - & & & - \\
\hline $30 / 11^{\circ}$ & & 2 & & 1 & - & & & - \\
\hline $31 / 11^{\circ}$ & 4 & $=8$ & - & $=1$ & - & 1 & $=4$ & \\
\hline
\end{tabular}

Táboa 2. Variantes da representación da contracción da preposición \{de\} e o artigo determinado en Cantares gallegos, por pregos.

Pregos [1, 2, 3]: Predominio de do, da / dos, das. Prego [4]: Predominio de do, da / dos, das, pero frecuente dó, dá.

Prego [5]: O máis variable, predominio do, da / d'os, d'as, pero frecuentes dó, dá e dos, das. Prego [6]: Predominio de $d o$, da, pero alternan dos, das con d'os, d'as. Pregos [0 à 7, 8, 9, 10, 11]: Predominio de do, da / d'os, d'as. 


\begin{tabular}{|c|c|c|c|}
\hline DE & UN / UNHA & ESTE, ESE, AQUEL, EL & outros \\
\hline $\mathrm{P} / 0$ & d'un (3) d'unha, de unha & d'esta, d'esto, d'esas, d'aquela; de aquelas & \\
\hline $3 / 1^{\circ}$ & d'un, d'una & & \\
\hline $4 / 2^{\circ}$ & d'un & d'eses & \\
\hline $5 / 2^{\circ}$ & d'unha (2) & d'ela, dela, delas & \\
\hline 6 & & & d'outros \\
\hline $7 / 3^{\circ}$ & d'unha & d'el & \\
\hline $10 / 3^{\circ}$ & & d'aquel & \\
\hline $11 / 4^{\circ}$ & d'un (2) & & \\
\hline $124^{\circ}$ & d'un & & \\
\hline $14 / 4^{\circ}$ & & d'eses, d'aquel & \\
\hline $16 / 5^{\circ}$ & & d'ela & \\
\hline $17 / 5^{\circ}$ & & d'el & \\
\hline $18 / 5^{\circ}$ & d'unha & de esta & \\
\hline $19 / 6^{\circ}$ & d'unha & d'estos, d'elas & \\
\hline $20 / 6^{a}$ & d'un & d'estos, d'estes & \\
\hline $21 / 7^{\circ}$ & d'un (2) & & \\
\hline $22 / 7^{\circ}$ & d'un (2) & d'este & \\
\hline $23 / 7^{\circ}$ & d'un, d'unha & d'el, d'eles & d'un arpa \\
\hline $24 / 8^{\circ}$ & d'un, d'unha & d'eles & \\
\hline $25 / 8^{\circ}$ & & d'estes & \\
\hline GG $/ 9^{\circ}$ & d'un & d'eses & \\
\hline $26 / 9^{\circ}$ & & d'aquel & \\
\hline $28 / 10^{\circ}$ & d'un (4) & d'este, d'ela & \\
\hline
\end{tabular}

Táboa 3. Variantes da representación da contracción da preposición \{de\} co artigo indeterminado e cos demostrativos en Cantares gallegos, por pregos. 


\begin{tabular}{|c|c|c|c|c|c|}
\hline $\mathrm{CON}$ & O & A & OS/AS & UN/UNHA & AQUEL \\
\hline $\mathrm{P} / 0$ & có, c'o, c’ó & có á & c'os (2), c'as & c'unha (3) & \\
\hline $1 / 1^{\circ}$ & có (3) & & cás & & \\
\hline $2 / 1^{\circ}$ & & & & c'unha & \\
\hline $3 / 1^{\circ}$ & co & cá & c'as & & \\
\hline $4 / 2^{\circ}$ & có (2) & cá & & & \\
\hline $5 / 2^{\circ}$ & & & c'os, c'as (2) & & c'aqueles (2) \\
\hline $6 / 2^{\circ}$ & có (2) & & c'as (4) & c'unha & con ela \\
\hline $7 / 3^{\circ}$ & co & c’á & & & c'aquel \\
\hline $9 / 3^{\circ}$ & & c'á (2) & c'as & & \\
\hline $12 / 4^{\circ}$ & & $\mathrm{ca}$ & & & \\
\hline $14 / 4^{\circ}$ & có (2) & & cós & & \\
\hline $16 / 5^{\circ}$ & có & cá & c'os & & \\
\hline $17 / 5^{\circ}$ & có (2) & & c'os & & \\
\hline $18 a^{1} 5^{\circ}$ & có & & c'os, c'as (3) & & \\
\hline $18_{b} / 6^{\circ}$ & & có á & & & \\
\hline $19 / 6^{\circ}$ & & c'á (2) & $\begin{array}{c}\text { c'os } 2-\text { cós, } \\
\text { c'as } 3\end{array}$ & & \\
\hline $21 / 6^{\circ}$ & & c’á, cá & & & c'aquelas \\
\hline $22 / 7^{\circ}$ & có & & c'os & & \\
\hline $23_{\mathrm{a}} / 7^{\circ}$ & có (3)- c'ó (1) & $\begin{array}{c}\text { c’á (1) - co á (1) - c’o } \\
\text { á (1) }\end{array}$ & c'os, c'as & $\begin{array}{l}\text { c'un (2), } \\
\text { c'unha }\end{array}$ & \\
\hline $23_{\mathrm{b}} / 8^{\circ}$ & có (4) - c’ó (2) & c'á (1) - co á (1) & & & \\
\hline $24 / 8^{\circ}$ & & & c'os (2) & & \\
\hline $25 / 8^{\circ}$ & & & & con un & \\
\hline GG $/ 9^{\circ}$ & c'o & c’oá & cós, cás, c’as & & \\
\hline $26_{a} / 9^{\circ}$ & & c’á & & c'un & \\
\hline $26_{b} / 10^{\circ}$ & c'o & & & & \\
\hline $28 / 10^{\circ}$ & con o & c'á, c'a & c'os (2), c'as (2) & c'un (2) & \\
\hline $30 / 11^{\circ}$ & c'ó (2) & & & c'uns (3) & \\
\hline
\end{tabular}

Táboa 4. Variantes da representación da contracción da preposición \{con\} cos artigos determinado e indeterminado e co demostrativo aquel en Cantares gallegos, por pregos.

O que máis chama a atención: 1) a representación con apóstrofe cando a preposición se xunta a artigo masculino singular $<$ 'o $\mathbf{}>$ (ocasionalmente, $<c^{\prime}$ ó $>$ ), nos pregos 0 e $7,8,9,10,11 ; 2)$ a representación sen apóstrofe e con acento cando a preposición se xunta a artigo feminino singular <cá> (ocasionalmente, co plural: <cás>), nos pregos 1, 2, 4, 5 e 6. 


\begin{tabular}{|c|c|c|c|c|c|}
\hline$E N$ & $+\mathrm{O} / \mathrm{A}$ & + UN / UNHA & $\begin{array}{l}\text { + ESTE, ALGUN, } \\
\text { OUTROS }\end{array}$ & OUTROS & $\begin{array}{c}\mathrm{MO}, \\
\mathrm{CHO}, \\
\mathrm{LLO}\end{array}$ \\
\hline Prólogo & ná & nún & $\begin{array}{c}\text { naquel, nesto, neste (2), } \\
\text { nesta }\end{array}$ & & \\
\hline$\left[\mathbf{1}^{\mathbf{o}}\right] / 1$ & $\begin{array}{l}\text { no (2), na (9), } \\
\text { nos (3), nas (2) }\end{array}$ & & & n'aurora & mó (6) \\
\hline 2 & (2) & nunh'alborada & & & \\
\hline 3 & ná / no, na (3) & nun, n'un, nunhas & & & \\
\hline$\left[2^{\circ}\right] / 4$ & & nun & & & chó \\
\hline 5 & & nun, nunha & n'esta, n'aquella & & \\
\hline 6 & ná & & n'ela & & \\
\hline$\left[3^{\circ}\right] / 7$ & nás (1), nas (3) & & & & \\
\hline 8 & no & & & & má \\
\hline 10 & nó (2), no, na (2) & & & & ch’á (2) \\
\hline $\begin{array}{c}{\left[4^{\mathbf{o}}\right] /} \\
11 \\
\end{array}$ & nós & & & & \\
\hline 12 & no, na & & & n’espuma & $\begin{array}{c}\text { ma / llá } \\
(2)\end{array}$ \\
\hline 14 & no, ná & & na quel & & \\
\hline $\begin{array}{c}{\left[5^{\circ}\right] / /} \\
15 \\
\end{array}$ & $\begin{array}{c}\text { nós / no, nos, } \\
\text { nas (2) }\end{array}$ & n'unha & n'outro & n'azulada & \\
\hline 16 & $\begin{array}{l}\text { ná / no (4), na } \\
(2), \operatorname{nos}(2)\end{array}$ & nun & & & \\
\hline 18 & $\begin{array}{c}\text { nó, ná / no (7), } \\
\text { na (2) }\end{array}$ & nunh'alborada & & & \\
\hline $\begin{array}{c}{\left[6^{\circ}\right] / /} \\
19 \\
\end{array}$ & $\begin{array}{l}\text { ná (2), nás / no, } \\
\text { na (3), no, nas }\end{array}$ & & n'aquesta, neste, nesto & & \\
\hline 20 & na (3), nas (4) & & & & \\
\hline 21 & $\begin{array}{c}\text { ná, nás / no (2), } \\
\text { na (3) }\end{array}$ & & & & \\
\hline $\begin{array}{c}{\left[7^{\mathbf{0}}\right] /} \\
22\end{array}$ & $\begin{array}{c}\text { no (3), na (3), } \\
\text { nas (4) }\end{array}$ & nunha & naquelas, naqueles, nesta & & \\
\hline 23 & no (4), nas (2) & & nalgún, neste, naquel & n'antreaberta & \\
\hline $\begin{array}{c}{\left[8^{\circ}\right] / /} \\
24 \\
\end{array}$ & nos & nunha & nelas & & \\
\hline 25 & no (4) & nun & & & \\
\hline $\begin{array}{c}{\left[9^{\circ}\right] / /} \\
G G \\
\end{array}$ & $\begin{array}{c}\text { no (1), na (2), nas } \\
(2), \text { ná }\end{array}$ & & nélas & & \\
\hline 26 & no (6), na (1) & & & & \\
\hline $\begin{array}{c}{\left[\mathbf{1 0}^{\circ}\right] /} \\
27\end{array}$ & na, nos (2) & & & & \\
\hline 28 & $\begin{array}{l}\text { nó, ná / no (3), } \\
\text { na (3), nos, nas }\end{array}$ & nun & nesta, nel, nela (2) & n'Adina & \\
\hline $\begin{array}{c}{\left[\mathbf{1 1}^{\mathbf{0}}\right] / /} \\
29 \\
\end{array}$ & no & & & & \\
\hline 30 & no, nos, nas & & & n'alborada & \\
\hline
\end{tabular}

Táboa 5. Variantes da representación da contracción da preposición \{en\} cos artigos determinado e indeterminado e cos demostrativos; e mais representación dos encontros pronominais $\{\mathrm{mo}$, cho, llo\} en Cantares gallegos, por pregos. Nótese: $\mathrm{O}$ emprego do apóstrofe, sempre esporádico, rexístrase unicamente nos pregos 1 a 6 . 


\begin{tabular}{|c|c|c|c|}
\hline Prego & POR + O, A, OS AS & TODOS & OUTRAS \\
\hline 0 & pó-lo / po-lo, pó-la / po-la, po-los & tódal-as & \\
\hline 1 & pó la, pó las & tódalas & \\
\hline 2 & pó lo, pó la & & vó lo pido, \\
\hline 3 & pó lo, pó la / po la & tódolos & \\
\hline 4 & pó lo, pó las & tódalas & de vó lo pensara \\
\hline 5 & pó lo, pó la, pó los & gardal'o pano \\
\hline 6 & pó la, pó las & & escorrenta-los \\
\hline 7 & pó lo, pó la, pó los & & burros \\
\hline 8 & pó lo, pó las & & mate-la pita \\
\hline 9 & pó-lo, pó-la, pó-los & & \\
\hline 10 & pó-la, pó-los & & \\
\hline 11 & pó-lo, pó-los & & \\
\hline 12 & 0 & & \\
\hline
\end{tabular}

Táboa 6. Representación do alomorfo $\{$ lo $\}$ do artigo determinado en Cantares gallegos, por pregos. 


\section{APÉNDICE 3. ETIMOGRAFÍA NUN AUTÓGRAFO ROSALIANO?}

Juan Naya (1953, 68-72), ao dar noticia dos autógrafos rosalianos que recollen cantigas que circulaban nas comarcas ao occidente de Compostela, relaciónaos cun vello proxecto de Murguía: a compilación dun cancioneiro popular galego, para o que encargaría á súa dona a recolla de materiais daquelas bisbarras. $\mathrm{O}$ mesmo Naya, que, como antes indicamos, cońeceu un autógrafo con máis follas ca as que nós publicamos (un deles chegou á Fundación Penzol a través de Xosé María Álvarez Blázquez), edita no lugar citado algúns destes textos, aínda que sen reproducir fielmente as grafías do orixinal (Naya 1953, 70-72), polo que estas versións non son útiles para o noso obxecto.

Secomasí, indo ao asunto que nos interesa, o manuscrito autógrafo (?) núm. 3a presenta unhas características grafemáticas que o singularizan nos seguintes aspectos: ausencia do apóstrofo e do guión (non se rexistran, ao menos no folio que coñecemos), adopción do dígrafo $<\mathrm{nh}>$ no canto da solución usual da autora, $<\mathrm{n}-\mathrm{h}>$; e adopción das solucións etimográficas en lugar do $<\mathrm{x}>$. Ou o manuscrito non é autógrafo ou indica unha mudanza de pautas gráficas da autora. Quizais esta poida relacionarse co proxecto de Murguía, de compilación e publicación dunhas Rimas populares de Galicia. Precedidas de un estudio acerca de la poesía popular gallega ${ }^{16}$, para a cal este elaboraría uns criterios gráficos que Rosalía adoptaría na transcrición do material que foi recollendo con destino a esta obra. Semella que o primeiro anuncio da aparición desta obra apareceu en 1878, e contra 1895 estaría rematada. Barreiro Fernández (Murguía 2012, 395-401) sinala o interese de Murguía pola literatura popular xa desde 1858, en tempos do seu contacto co círculo de intelectuais agrupado arredor de El Museo Universal, e especula sobre o paradoiro do manuscrito da obra en aprezo, que quedou inédita.

En todo caso, a partir de 1878, Murguía dá ao prelo diversos textos recollidos do pobo, e en 1881 dá sinais de estar especialmente interesado no asunto ${ }^{17}$. Probablemente, as notas autógrafas de Rosalía (se finalmente estas o son) procedan deste período ou sexan un pouco posteriores a el, cando Rosalía deixa de vivir en

16 Título completo que lle dá Álvarez Ruiz de Ojeda 2000, 57.

17 Véxase por caso o seu artigo «Poesía popular gallega», La Ilustración Gallega y Asturiana III, 2 (1881), 17. 
Compostela e se instala primeiro en Lestrobe (1881) e despois na Matanza en Padrón (1883).

Temos un testemuño directo do cambio de criterio ortográfico de Murguía: no prólogo ás Rimas populares de Galicia, redactado despois de 1895, Manuel Murguía manifesta a súa clara opción pola etimografía, ou, para máis exactamente, pola «ortografía portuguesa», atendendo, como el asegura "como es justo, al origen de las voces» ${ }^{18}$ :

- Había llegado a ser para mi, cosa de verdadero empeño, la publicación del presente libro. Aparte de su importancia manifiesta y el influjo que espero que ejerza bajo varios conceptos, como lo había anunciado tanto tiempo ha, no pasaba día sin que me recordase el compromiso contraído. A pesar de ello, graves inconvenientes me impedían arriesgarme, siendo el primero y principal el deseo que tengo de que, como cosa de la musa popular, y por esto mismo obra nacional, su ortografía, agena á los caprichos de la que cada autor que escribe en gallego tiene para su uso, fuese lo que se dice nacional tambien, y si tanto pudiese alcanzarse, definitiva. Esperaba por ello que la Academia Gallega en la cual pusimos todos tantas esperanzas, se decidiese y publicase, la verdadera ortografía de nuestro romance, ó cuando menos la más aceptable. El fracaso experimentado de la Academia en su creación, nos dice bien claro que ya no la tendremos jamás, y por lo mismo que en la cuestión de la ortografía, seguiremos por largo tiempo en la amable anarquía á que nos tiene condenados la voluntariedad y á veces la ignorancia de los que escriben en el idioma gallego.

- Dispuesto a salvar tan grave escollo, hube de decidirme por lo más racional. El gallego y el portugués, me dije, son uno mismo en el origen, gramática y vocabulario. ¿Por que no aceptar la ortografia portuguesa? Si nos fue comun en otros tiempos, ¿por que no ha de serlo de nuevo?

- Solo un total olvido entre nosotros, de la lengua hermana, pudo hacer que se alcanzase y prevaleciese la especial confusión con que escribieron y escriben el gallego; atendiendo los unos, como es justo, al origen de las voces, atendiendo los otros á lo que da de si la fonética, y en fin mezclando los mas sin tino ni concierto ambos sistemas. Para evitar tan

18 Edita o texto parcialmente Isabel Seoane 2000, 141, a quen seguimos no fragmento que ela publica. Previamente, fora exhumado no artigo "A Construcción dunha ortografía nacional. Manuel Murguía», asinado co pseudónimo Alba Ma Ferrete Mariño e aparecido inicialmente en www. revistaomnibus.com, Lingua, 2, Agosto, 1999. Sobre as ideas lingüísticas de Murguía pode verse Monteagudo 2000. 
grave inconveniente y sobre todo para echar de una vez las bases de una ortografía con la cual podamos y debamos conformarnos, me decidí por de pronto á seguir la portuguesa, modificada en aquella parte en que puede sin peligro asimilarse á la que usamos. Un docto amigo mío el Sr. Don Floro Vaamonde, se encargó de esta tarea, y el fue quien copió como conviene las composiciones que forman el presente volumen. A el pues los aplausos (p. 41).

De feito, a pouco de ser fundada a Real Academia Galega baixo a presidencia de Murguía, a "Comisión de Ortografía» creada no seu seo adoptou un acordo a favor da solución etimográfica (Monteagudo 1999, 378-79). Canto a Rosalía, se realmente o manuscrito vertente é autógrafo, o seu uso da grafía etimolóxica limitouse a aquela tarefa concreta de compilación de cantares populares destinados ao proxecto do esposo, pois nin en Follas novas nin, máis significativamente aínda, na súa derradeira composición coñecida en galego, «Dend' as fartas orelas do Mondego», impresa nun Almanach das senhoras para 1885 publicado en Lisboa en 1884 (Bouza Brey 1948; reproducido tamén por Pociña / López en Castro 2004, 320-21) fixo a menor concesión á etimografía.

Por parte, a innovación do $<\mathrm{x}>$ que aparece en Follas novas non sabemos a quen atribuírlla. Case con absoluta certeza, non a Rosalía. Podería deberse á intervención de Murguía, pero, neste caso, trataríase dun experimento puntual, sen precedentes cońecidos nin continuidade. En que baseamos esta afirmación? Como é sabido, seis poemas do libro viñeran a lume previamente ${ }^{19}$ : «Ruinas», tradución dun poema de Ventura Ruiz Aguilera (FN III.xxviii), fora publicado en tres ocasións, 1865 (na obra Armonías y cantares, do autor traducido), 1873 (na obra Elegías y cantares, do mesmo) e 1874 (El Heraldo Gallego); Padron, Padron» (FN II. xxxiii) en 1872 (El Correo de Galicia); "Amigos vellos» (FN II.xxviii), publicado en 1876 co título "N’o tempro» (El Heraldo de Galicia), "Aquel romor de cantigas» (FN I.xiv) en 1878 (La Ilustracion Gallega y Asturiana); e, finalmente, o que é máis significativo para o noso argumento, tendo en conta a relación de Murguía coa revista onde se publica, «Na catredal» (FN II.v), estampado dou ou tres meses antes de que o libro saíse do prelo, isto é, en febreiro de 1880 (tamén La Ilustracion Gallega y Asturiana) — Follas novas saíu do prelo en finais de abril

19 Para isto, véxase Monteagudo / Vilavedra en Castro 1993, 19-20 e 413-18. 
ou primeiros de maio (Monteagudo / Vilavedra en Castro 1993, 21-23). Pois ben, en ningunha das edicións citadas dos devanditos textos, aparece a grafía $<\mathrm{x}>$, incluíndo -insistimos - as estampadas en La Ilustración Gallega y Asturiana, revista da que Murguía foi director e á que aínda cando deixou de selo se mantivo moi próximo (Barreiro 2012, 384-94).

A maior abundamento, pódese engadir que tampouco nos poemas de Follas novas que foron editados inmediatamente despois da aparición do libro se emprega a grafía innovadora en aprezo: tal é o caso do xa citado "Padrón, Padron», reproducido en El Heraldo de Galicia, en setembro de 1880; "Tristes recordos», editado en outubro do mesmo ano nesa mesma revista, e máis tarde, en decembro, en La Ilustración Gallega y Asturiana; e mais «Na catredal», republicado en outubro no Almanaque de El Correo Gallego. O mesmo acontece, como acabamos de sinalar, coa única composición nova en galego (non recollida en Follas novas) que foi publicada en vida de Rosalía, «Dend'as fartas orelas do Mondego». 


\section{APÉNDICE 4: AUTÓGRAFOS}

[1]

Tes un-ha frente d'apolo,

Y uns ollos tes verde mar.

$\mathrm{Na}$ miña vida vin outros

De mais hermoso mirar

Pero con eles non fies

Galan, de me namorar.

Que choras ... galan, a moitos

Cal ora a ti vin chorar;

Que morres por min ...

A cantos ll'oin o mesmo cantar

$E$ inda estan vivol'os probes,

Difuntos qu'asi falar.

Gustanm'os teus ollos verdes.

¡Como no m'an de gustar!

Gustame galan miralos

Cando me veñen mirar

Mais n'ey de ser eu quen d'eles

Nin d'outros se namorar.

Fonte: Naya 1953, 28-29 (con reprodución facsímile do manuscrito).

1.- N] Apolo. |2.-MS] Y corrixido sobre $y$. |5.-N] fies: fico. | 12.-N, P/L] defuntos. |15.-MS]

Gustame mirarche corrixido para Gustame mirarme n'eles, e despois cancelado.

[2]

Aquí vexo os seus cans y os seus amigos

Aqui vexo a sua casa e os seus nabals

E s'alá de soidas me consumia,

Ora de pena me consumo acá.

Fonte: Naya 1953, 63 (con reprodución facsímile do manuscrito).

2.- nabals: primeiro escribiuse <nabales $>$, despois riscouse o <e>. 


\section{[3a]}

Estrelińa do luceiro

quen ten amores non dorme

sinon ó sono primeiro.

Estas coplas o estribillos de tres versos se cantan por lo regular hacia la parte Occidental de Galicia, cantándolas con cierto tono especial.

Queridińa dame un ay

Damo caladiñamente

Sin_o saber tua nay.

Janińo, Jan de Borela

para que querela cama

Si no vas dormir á ela.

Miña cariña de rosa

Meniña á a_tua orta

atravesalle un codeso [codeso: 'retama']

qu' omeu becerro e ladron

ha de volver po.lo veso

[costumbre, golosina agradable]

|| Ovellińa sin pastor

Aviva o teique teique

Mentras falo á o meu amor.

Quigera os ríos cerrar

Cunha chaviña d' aceiro,

Rio da ponte Nafonso

ti has de ser ó primeiro. 
Campanas de Bogallido

Cando vos oyo tocar

reviraseme o sentido.

As meniñas de Sarnon

corbatiña corbatiña

faldra da camisa non.

Anque che son barcalesa

Anque che son de Barcala

Anque che son no me pesa.

O tocador das ferreñas

Deralle eu si pudera

A sangre das miñas venas.

Case ten ó pe ligeiro | [...]

Fonte: Fundación Penzol. Véxase Naya 1953, 67-74. Edita, adaptanto a ortografía, os versos 1-3, 6-8 e 24-26.

7.- dame. |8.- Si no. | 10.- querela la cama. | 13.-á a tua. | 15.- he, corrixido. | 16.-po lo. | 21.- da aceiro. | 27.- meñinas. |36.- ligeiro: cun borrón que parece delatar dúbidas canto a grafía $<\mathrm{g}>$.

\section{$[3 b]$}

Si por min perdiche o sono

Agora podes dormir

Eu como son picarona

O que me tocan bailo

Dime cando estaba lonxe

Si te acordabas de min

Mandoche o meu corazon

Cas chaviñas par'a o abrir

Nin eu teño mais que darche

Nin ti mais que me pedir 
Ahí tes o meu corazon

Si ó queres matar ben podes

Pero como estas di dentro

Tamen si ti o matas morres

Un xastre y un zapateiro

Baixaron o inferno xuntos

$\mathrm{O}$ xastre baixou por varas

O zapateiro por puntos

Son morena, son morena

Son morena, son bastante

$\mathrm{O}$ que no me queira ver

Colla o camiño de diante

Adios rios, adios fontes,

Adios regatos pequenos

Adios vista dos meus ollos

Non sei cando nos veremos

Este pandeiro que toco

Ten os aros de sanguiño

Si se toca en Ribadavia

Resoa no Carballiño

Teño sono, teño sono

Voume votar á dormir

Qu'o que de dios estivere

Ás miñas mas á de vir

Si o mar tivera barandas

Fórate ver o Brasil,

Mais o mar non ten barandas

Meu amor por donde ei d'ir? 


\section{Tocay ese pandeiriño}

Agarraino po lo medio

Por que lle faga parola

Os que estan de parrafeo

Fonte: Arquivo Histórico Municipal da Coruña. Reprodución dixital: http://rosaliadecastro.org /wp-content/ uploads/2013/05/ExposicionCantares150Anos.pdf.

8. para o abrir: o apóstrofo entre $\mathrm{o}<\mathrm{r}>\mathrm{e} \mathrm{o}<\mathrm{a}>$ foi introducido posteriormente. |13. dentro: primeiro escribiuse $<$ tendro $>$ e despois corrixiuse. | 30. Resoa: primeiro escribiuse <resona>, despois foi corrixido. | 34. Ás miñas mas: o til sobre o $<\mathrm{A}>$ ofrece dúbidas. | 38. d'ir: primeiro escribiuse $<$ dir $>$, despois introduciuse o apóstrofo. | 40 Agarraino: corrixido sobre <Agairraino $>$. 
[4]

-Poida... mais â tua bodega

Dime cando chegaremos.

Teño un-ha sede dos deños,

e a mais penso que lostrega

-O qu’ay, meu compañeiriño

Non son lostrégos nin rollos.

E que tes lume nos ollos

E a gorxa pídeche viño.

Ey... mobe eses pes lixeiro

Qu'estamos o pe da pipa.

E bebe, que di Filipa

Qu'a sede abolve o calleiro.

-Jeem ... Dio lo pague qu'e forte.

Bebin canto me botache

Tes un viño que ... carache,

Fai rasucital a morte:

-¡E logo si? $\mathrm{Na}$, que deño!...

Nin o d'un padre Benito.

-E bon! mais o dito dito.

Inda e millor o qu'eu teño

-Compadre ... non digas tal

Si queres ser meu amigo.

-Pois vas a volver comigo.

A ver si minto catral ...

-Que volver nin que cachopa ...

Mais po la tema ... volvamos.

Vere(re)mos en que quedamos

An qu'estou coma un-ha sopa

E indo e vindo no camińo.

Tanto os compadres bebeno,

que nunca en xamas volbeno

A probar augua nin viño. 
Henrique Monteagudo

C'o ventre com'un-ha uba,

Tras de tanta e tanta proba,

Levanonos para a coba

Dend'o mesmo pe da cuba.

Fonte: Cuadernos de Estudios Gallegos, 22 (1967), 253-54. 


\section{REFERENCIAS BIBLIOGRÁFICAS}

ALBUM de la Caridad. Juegos Florales de La Coruña en 1861, seguido de un mosaico poético de nuestros vates gallegos contemporáneos, A Coruña, Imprenta del Hospicio provincial á cargo de D. Mariano M. y Sancho, 1862. [Edición facsímile en Madrid, Ediciones Giner, 1989].

Alonso Montero, Xesús (1970): Constitución del gallego en lengua literaria. Datos de una problemática cultural y sociológica en el siglo XIx, Lugo, Ediciones Celta.

Álvarez RuIz De OJEDA, Victoria (2000): «Para unha bibliografía, correcta e completa, de Manuel Murguía», Boletín da Real Academia Galega, 361, 15-58.

Barreiro Fernández, Xosé Ramón (2012): Murguía, Vigo, Galaxia.

Bel Ortega, Fernando (1991): Vida e obra de Francisco Añón, A Coruña, Fundación Barrié de la Maza.

Bouza Brey, Fermín (1946): «Escritos no coleccionados de Rosalia de Castro (VI). Conto gallego», Cuadernos de Estudios Gallegos, 2, 279-94. [Reproduce a edición aparecida en Almanaque Gallego, 1923, 95-104. Reprodución facsímile desta publicación en Santiago de Compostela, Consello da Cultura Galega, 2012, vol. VI, 1923-27].

BouZa Brey, Fermín (1948): «Escritos no coleccionados de Rosalia de Castro (IX). Dende as fartas orelas do Mondego", Cuadernos de Estudios Gallegos, 3, 125-27.

Bouza Brey, Fermín (1968): «Textos y documentos. Xuizo do ano, poesía desconocida de Rosalía en el 'Calendario Gallego' de Soto Freire», Cuadernos de Estudios Gallegos, 23, 237-40.

Carballo Calero, Ricardo (1967): «Comparación dun fragmento conservado do orixinal dun poema de Rosalía co testo impreso en 1909", Cuadernos de Estudios Gallegos, 22, 252-54. [Reproducido en R. Carballo Calero, Estudos rosalianos. Aspectos da vida e obra de Rosalía de Castro, Vigo, Galaxia, 1979, 148-51].

Carballo Calero, Ricardo (1981): Historia da literatura galega contemporánea, Vigo, Galaxia.

Carvalho Calero, Ricardo (1983): «A língua literária em 1880», en idem, Da fala e da escrita, Ourense, Galiza editora, 60-65.

CAstro, Rosalía de (1861): «iAdios qu’eu voume», El Museo Universal, 47, 375. [Reprodución dixital na Biblioteca Virtual Miguel de Cervantes: http://www.cervantesvirt ual.com/partes/234105/el-museo-universal/]. Novamente editado en Galicia. Revista Universal de este Reino, núm. 16 (1862), 252-53. [Reprodución dixital no espazo web da Real Academia Galega: http://www.realacademiagalega.org/ hemerotecavirtual\#paxinas_numero.do?id=810\&d-447263-p=12\&current_page=2].

Castro, Rosalía de (1863): Cantares gallegos, Vigo, Establecimiento tipográfico de J. Compañel. [A edición facsímile máis fiel é a promovida polo Concello de Vigo en 1985. No ano 2013 veu a lume outra, promovida pola Xunta de Galicia, o Consello da Cultura Galega e o Parlamento de Galicia, que inclúe ao final os poemas engadidos na segunda edición].

Castro, Rosalía (1864): Contos da miña terra, A Coruña, El Avisador. [Reprodución dixital no espazo web da Real Academia Galega: http:// www.realacademiagalega.org/biblioteca-virtualmonografias\#paxinas. do?id=306]. [Segunda edición de 1868 en El Eco Ferrolano, reproducida en facsímile en Betanzos, Asociación Cultural Eira Vella, 2012].

Castro, Rosalía de (1872): Cantares gallegos, Madrid, Librería de D. Leocadio López. [Véxase comentario á edición de 1863]. 
Castro, Rosalía de (1880): Follas novas. Versos en gallego, Madrid, La Ilustración Gallega y Asturiana / A Habana, La Propaganda Literaria. [Edición facsímile da Real Academia Galega, 1982].

Castro, Rosalía (1970): Cantares gallegos. [Prólogo e notas: Fermín Bouza Brey]. Vigo, Galaxia.

Castro, Rosalía (1973): Poesias, Padrón, Patronato Rosalía de Castro. [Edición preparada pola Cátedra de Lingüística e Literatura Galega da Universidade de Santiago de Compostela].

Castro, Rosalía (1977): Obras completas, 2 vols. [Recopilación e introducción por Victoriano García Martí. Nueva edición aumentada por Arturo del Hoyo]. Madrid, Aguilar.

Castro, Rosalía (1992): Poesía en galego competa. Vol. I: Cantares gallegos. [Edición de Andrés Pocińa e Aurora López]. Santiago de Compostela, Sotelo Blanco.

Castro, Rosalía de (1993): Follas novas. [Edición de Henrique Monteagudo e Dolores Vilavedra]. Vigo, Galaxia.

Castro, Rosalía (1995): Cantares gallegos. [Edición de María Xesús Lama López]. Vigo, Galaxia.

Castro, Rosalía (2003): Poesía en galego competa. Vol. II: Follas novas. Poemas soltos. Traduccións. [Edición de Andrés Pociña e Aurora López]. Santiago de Compostela, Sotelo Blanco.

Castro, Rosalía (2013): Cantares gallegos. [Estudo, edición, notas e comentarios: Anxo Angueira]. Vigo, Xerais.

Dobarro, Xosé M. (1991): «Dous poemas inéditos de Alberto Camino», en M. Brea / F. Fernández Rei (coords.), Homenaxe ó profesor Constantino García, Santiago de Compostela, Universidade, vol. 2, 443-49.

Fernández Salgado, Benigno / Henrique Monteagudo (1995): «Do galego literario ao galego común. O proceso de estandarización na época contemporánea», en H. Monteagudo (ed.), Estudios de sociolingüística galega, Vigo, Galaxia, 99-176.

Ferrete Mariño, Alba M.a (1999): «A Construcción dunha ortografía nacional. Manuel Murguía», en www. revistaomnibus.com, Lingua, 2, agosto, 1999. [Reproducido no Portal Galego da Língua: http://www.agalgz.org /modules. php?name=Encyclopedia\& op= content\&tid=118 (consulta realizada o 25/03/2013)].

Filgueira Valverde, Jose (1967) «Escritos no coleccionados de Rosalía de Castro. Unha boda na aldea», Cuadernos de Estudios Gallegos, 22, 257-63.

Fontorra Suris, Lydia (2008): «Rosalía de Castro e o Almanaque de Galicia», Revista de Estudos Rosalianos, 3, 75-91.

Fontoira Suris, Lydia (2011): «Dos Cantares populares de Galicia a Cantares gallegos. El Eco Escolar e a primeira edición de 'Un repoludo gaiteiro'», Revista de Estudos Rosalianos, 4, 159-82.

Lorenzo, Ramón (1986): «A lingua literaria na época de Rosalía», en Actas do Congreso internacional de estudios sobre Rosalía de Castro e o seu tempo, Santiago de Compostela, Consello da Cultura Galega / Universidade de Santiago de Compostela, III, 7-50.

Monteagudo, Henrique (1999): Historia social da lingua galega. Idioma, sociedade e cultura a través do tempo, Vigo, Galaxia.

Monteagudo, Henrique (2000): «As ideas lingüísticas de Manuel Murguía», en Congreso sobre Manuel Murguia, Santiago de Compostela, Xunta de Galicia, 219-45.

Monteagudo, Henrique (2003): «A demanda da norma. Avances, problemas e perspectivas no proceso de estandarización do idioma galego», en H. Monteagudo e X. Bouzada (coords.), Elaboración e difusión da lingua, Santiago de Compostela, Consello da Cultura Galega, 37-129. 
Monteagudo, Henrique (2004): «O ideario lingüistico de Manuel Curros Enríquez», en X. Alonso Montero / H. Monteagudo / B. Tajes Marcote (eds.), Actas do I Congreso Internacional "Curros Enríquez e o seu tempo", Santiago de Compostela, Consello da Cultura Galega, I, 311-42.

Murguía, Manuel (1858): «Poesia gallega contemporánea», en El Museo Universal núm. 2, 10-11, núm. 4, 30-31, núm. 6, 42. [Reproducido en J. A. Durán (1998), Prosas recuperadas. O periodismo de Manuel Murguía. Antoloxía básica, 1853-1921, Madrid, Real Academia Galega / Fundación Caixa Galicia, 101-15].

Murguía (1881): «Poesía popular gallega», La Ilustración Gallega y Asturiana, III:2, 17.

Murguía, Manuel (1886): Los precusores, A Coruña, Latorre y Martínez Editores. [Edición facsímile A Coruña, La Voz de Galicia, 1976].

Naya Pérez, Juan (1953): Inéditos de Rosalía, Padrón, Patronato Rosalía de Castro.

Pociña, Andrés / Aurora López (1991), Rosalía de Castro. Documentación biográfica y bibliografía crítica, 3 vols., A Coruña, Fundación Barrié de la Maza.

Ríos Panisse, María do Carme (1995): “Contos da miña terra’ (1864), primeira edición do 'Conto gallego’ atribuido a Rosalía de Castro", Grial, 126, 257-80.

Rosa, Alberto Machado da (1958): «Subsídios para uma edição crítica. Traduçôes não-coleccionadas de Rosalia de Castro", en Homaxe a Ramón Otero Pedrayo no LXX aniversario do seu nacimento, Vigo, Galaxia, 219-36.

Seodne, Isabel (2000): «Un escrito de Murguía en galego. O recońecemento de Valentín Lamas Carvajal», Boletin Galego de Literatura, 24, 133-43.

TAibo, Victoriano (1948): «Textos y documentos. Escritos no coleccionados de Rosalía de Castro (IX). A volta do lar», Cuadernos de Estudios Gallegos, 3, 393-99.

Torres Regueiro, Xesús (2012): «O Conto Galego de Rosalía. Unha edición ferrolá asinada pola autora en 1868", Grial, 195, 118-23. 
